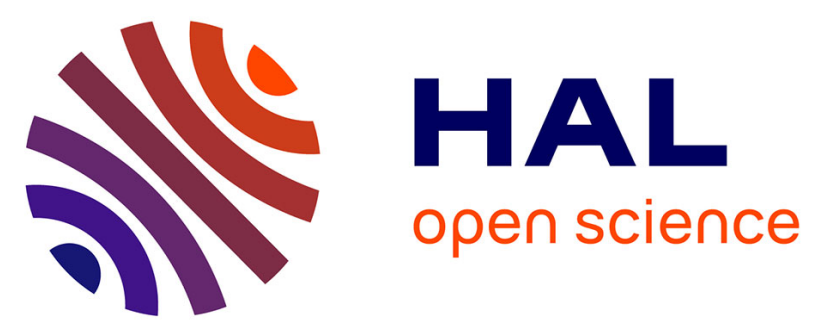

\title{
Modeling approaches to detect land-use changes: Urbanization analyzed on a set of 43 US catchments
}

Bahar Salavati, Ludovic Oudin, Carina Furusho-Percot, Pierre Ribstein

\section{To cite this version:}

Bahar Salavati, Ludovic Oudin, Carina Furusho-Percot, Pierre Ribstein. Modeling approaches to detect land-use changes: Urbanization analyzed on a set of 43 US catchments. Journal of Hydrology, 2016, 538, pp.138-151. 10.1016/j.jhydrol.2016.04.010 . hal-01311319

\section{HAL Id: hal-01311319 https://hal.sorbonne-universite.fr/hal-01311319}

Submitted on 4 May 2016

HAL is a multi-disciplinary open access archive for the deposit and dissemination of scientific research documents, whether they are published or not. The documents may come from teaching and research institutions in France or abroad, or from public or private research centers.
L'archive ouverte pluridisciplinaire HAL, est destinée au dépôt et à la diffusion de documents scientifiques de niveau recherche, publiés ou non, émanant des établissements d'enseignement et de recherche français ou étrangers, des laboratoires publics ou privés. 
Modelling approaches to detect land-use changes: urbanization analyzed on a set of 43 US catchments.

\author{
Bahar Salavati $^{\text {a,b }}$, Ludovic Oudin ${ }^{\text {a,b }}$, Carina Furusho-Percot ${ }^{c}$, Pierre Ribstein ${ }^{\text {a,b }}$ \\ (a) Sorbonne Universités, UPMC Univ Paris 06, UMR 7619 Metis, Case 105, 4 place Jussieu, F-75005 \\ Paris, France. \\ (b) CNRS, UMR 7619 Metis, Case 105, 4 place Jussieu, F-75005 Paris, France. \\ (c) IRSTEA, Hydrosystems and Bioprocesses Research Unit, Parc de Tourvoie, BP 44, 92163 Antony \\ Cedex, France. \\ Corresponding author. E-Mail: bahar.salavati@upmc.fr
}

\begin{abstract}
Paired catchment approach probably provides the most robust method to detect the effects of land-use change on catchments' flow characteristics. This approach is limited by the availability of two neighbor catchments with and without land-use change under similar climate conditions. This paper uses a hydrological model to detect the hydrological change caused by urbanization. This study describes 1) use a statistical method to evaluate change detection relative to variation of land use change, 2) simulation of non-urban condition for the urban catchment with an alternative approach, to this aim stream flow series of urban catchments have been reconstructed from the period that urbanization had not taken place yet, and 3) the model validation with observed data.
\end{abstract}

This paper intends to compare the flow changes detected by two different approaches: a regional statistical approach (the paired-catchment approach) and a conceptual modelling approach (the residual approach) on the particular case of urbanized catchments. To investigate the sensitivity of the results to the settings of both approaches, the comparison is made on a relatively large number of 43 catchments located in the United States, with relatively large gradients in terms of geomorphology and hydroclimatic characteristics. Results show that the two approaches are generally in relative good agreement in terms of detection and quantification of changes for the three flow characteristics analyzed (mean annual flow, high and low flow characteristics). Besides, it is found that the impact of urbanization on the catchment's hydrologic response is difficult to generalize: the proportion of nonsignificant trends, significantly increasing decreasing trends are on the 
same order of magnitude, even if an increase in urban areas generally has a greater impact on mean flows and high flows than on low flows.

Keywords: rainfall-runoff modeling, urbanization, paired catchments, land use change.

\section{Introduction}

\subsection{Urbanization and hydrology: well-spread ideas and subtleties}

Urbanization and population concentration are suspected of having multiple impacts on the catchment's hydrologic response (Geiger et al., 1987; Salvadore et al., 2015; Shaw, 1994).These impacts originate from a multiplicity of landscape modifications: the reduction of the perviousness of urban areas compared to natural land uses (see the review by Jacobson, 2011) is often highlighted but local water resource management activities such as natural pathways modifications (Motta and Tucci, 1984), detention basins and dams (FitzHugh and Vogel, 2011), inter-basin transfers, effluent discharge (Barringer et al., 1994) and/or groundwater pumping (Claessens et al., 2006) might also change significantly river flow dynamics and the amount of released water at the outlet of an urbanized catchment.

This multiplicity of modifications may potentially lead to compensations (Prosdocimi et al., 2015) and makes it difficult to synthetize the results from the numerous case studies related to the impact of urbanization on catchment's hydrologic response (Brath et al., 2006) and in some cases the observed data are not in full agreement with the wide-spread ideas that urbanization tends to increase flood occurrence (Brandes et al., 2005; Kauffman et al., 2009; Rose and Peters, 2001)and intensity while decreasing baseflow (Meyer and Wilson, 2002; Rozell, 2010). Beyond the site-specificity of the impacts of urbanization on catchment's hydrologic response, there is also the problem of measuring urbanization from a hydrological standpoint. Many efforts are still made to determine modifications of catchment imperviousness due to land use change (see e.g. Miller and Grebby, 2014). More often, population density and fractions of urban areas are usually derived to quantify urbanization, even if they are relatively poor proxies to impervious cover estimates (Shuster et al., 2005) and do not provide any information on the 
modification of landscape structures (see Jacobson, 2011; Weng, 2012) and on the drainage network modifications.

\subsection{Quantifying flow changes due to urbanization (or other land use change)}

The difficulty to determine the flow changes caused by urbanization also stems from the difficulty to quantify this change. Many facets of the hydrograph might be studied (Braud et al., 2013; Homa et al., 2013) such as shape, peak values, runoff yields, quick and slow flow volumes, flow duration curves, etc. These diverse hydrological characteristics might be impacted simultaneously by climate variability and urbanization, which makes it difficult to distinguish the causal effects of change (DeWalle et al., 2000; Harrigan et al., 2014; Hejazi and Moglen, 2008; Rougé and Cai, 2014; Yang et al., 2013). To cope with this climate confusing effect, urban hydrologists usually follow similar methodologies as "rural" hydrologists (Blöschl et al., 2007; Wagener, 2007). Three main approaches are generally considered, each one with its specific advantages and inherent drawbacks. These approaches are briefly described in the following (for more details on this issue see, Bronstert et al., 2002; McIntyre et al., 2014; Wagener, 2007).

1. The physically-based modelling approach is a priori the most rational way to investigate the impacts of urbanization on flow (Salvadore et al., 2015). While land use characteristics of the catchment are explicitly represented and all the processes influenced by them are modeled using parameters that, in theory, can be measured, in practice calibration is often required (De Roo et al., 2001; Niehoff et al., 2002). Past experiences showed interesting results of this approach (Li et al., 2009; Miller et al., 2014; Zhou et al., 2013). But modifications mean additional parameters and process descriptions which could increase model uncertainty (Niehoff et al., 2002) that remains difficult to quantify with this approach. This approach allows analyzing separately causal controls of urbanization on catchment hydrological behavior but the result is largely a reflection of the assumptions involved in the model structure (Blöschl et al., 2007).

2. The regional statistical approach is a top-down approach consisting essentially in trend analyses of long-term flow data series within a comparative framework including both catchments that encountered changes and steady-state catchments. 
This approach might either be applied on several catchments with a large gradient of land-use changes (DeWalle et al., 2000; Homa et al., 2013; Konrad and Booth, 2005; Rose and Peters, 2001) or just on a couple of contrasted catchments within the so-called paired catchment framework (Changnon and Demissie, 1996; Yang et al., 2013). The paired catchments approach is a straightforward method to separate the effects of land uses from climate. Originally developed for small forested catchments, the main difficulty to apply this approach on urbanized catchments lays in the role of different factors besides land-use change. It is almost impossible to find a 'non-disturbed' control catchment near an urbanized catchment: more often, the control catchment has also experienced land use modifications and/or is quite far from the urbanized catchment data series so that the environmental settings (climate, geology) are not fully similar (see the discussion by McIntyre et al., 2014). Besides, except for some experiments in forestry and agronomy, land use changes have no step changes and it is complicated to identify contrasted and stationary in pre-change and post-change periods.

3. The conceptual modelling approach attacks the problem from the other end, by looking for changes in the hydrological signal time-series in urbanizing catchments and then identifying repeatedly model parameters on successive time periods (see e.g. Hejazi and Moglen, 2008). Most of conceptual models will not have parameters explicitly related to land use and thus, the link between land use changes and parameters will be done a posteriori, in a statistical way (Lørup et al., 1998). Seibert and McDonnell (2010) reviewed and applied existing methodologies involving conceptual hydrological models to detect and quantify flow changes due to land use changes. These methodologies include (i) the residual approach (see also Kuczera et al., 1993; Salvadore et al., 2015) consisting in analyzing the residuals for the period after change of a model calibrated on the period before change, (ii) the comparison of model parameter values obtained on the period before and after change and (iii) comparison of streamflow time series simulated using different calibration periods (Andréassian et al., 2003; Schreider et al., 2002; Seibert and McDonnell, 2010; Siriwardena et al., 2006). Since paired 
catchment is probably more appropriate for small and spatially close catchments due to their similar characteristics (precipitation, soil condition etc.), conceptual modelling could be a way to deal with land use change impact detection in larger catchments for which control catchments are difficult to find (Andréassian, 2004; Andréassian et al., 2003; Seibert and McDonnell, 2010). The difficulties with the conceptual modelling approach is that changes in model parameters due to land use changes are not predictable due to the lack of clear relationships between model parameters and land use characteristics (Hundecha and Bárdossy, 2004). This clearly precludes the use of such models in scenario studies. Another difficulty is related to model uncertainties but these uncertainties can be taken into account in a rather straightforward way (see e.g. Seibert and McDonnell, 2010).

Whatever the chosen approach, uncertainties may be quite large and in some cases larger than the potentially detected flow changes. Whereas these uncertainties are usually recognized and sometimes tackled with uncertainty analyses, very few studies compared the different existing approaches to detecting and quantifying the flow changes due to land use change. Zègre et al. (2010) compared the conceptual modelling approach on a couple of catchments, in which one of them is less urbanized to the other. Bowling et al. (2000) explored flood magnitudes changes in 24 western Washington catchments where forest harvest and road construction occurred within a 70-year time period. They compared the results obtained from a paired catchment approach to the results obtained with a model based approach (the residual approach mentioned above). They found rather different results with the two approaches and they attributed these differences to the difficulty to find control catchments in the vicinity of the catchments that experienced land use changes. They clearly question the credibility of the different approaches utilized to quantify flow change.

\subsection{Scope of the paper}

The main objective of the paper is to compare the flow changes detected by two approaches: a regional statistical approach (the paired-catchment approach) and a conceptual modelling approach (the residual approach) on the particular case of urbanized catchments. To investigate the sensitivity of the results to the settings of both 
approaches, the comparison is made on a relatively large number of 24 catchments, with relatively large gradients in terms of catchment area, land use, climate settings, flow dynamics etc. This approach allows investigating the sensitivity of the detected impacts to these environmental settings. Except the study by Bowling et al. (2000) focusing on forest harvest, the authors are not aware of similar comparison studies on such a large catchment set, particularly in the case of urbanized catchments.

The paired catchment approach requires control catchments being selected in the vicinity of the urbanized catchments while the residual approach requires a hydrological model being calibrated on the urbanized catchments. To avoid as much as possible the specific problems due to the settings of both approaches, the selection of the control catchments (see Section 2) was undertaken with particular care and the hydrological model uncertainties were taken into account (see Section 3). Besides, an original framework is proposed in this paper (see Section 3) to compare the results of both approaches (Section 4).

\section{Methods}

\subsection{Paired catchment approach}

The rationale behind paired catchment analysis is based on the hypothesis that functional relationships exist between the flow variability of two spatially close catchments. Since the two catchments are assumed to be under similar climatic settings, the functional relationships remain valid until a change occurs on one of the catchments, usually referred as the disturbed catchment (Fig. 1). Although simple and straightforward, this approach is very limited by data availability, because paired catchments must be relatively closed to be considered under similar climate settings, but with a different land use history. Moreover, the number of concomitant observations on the catchments must be sufficient to identify significant functional relationships for pre- and post-change periods.

Unlike the usual applications of paired catchment approaches on step land use changes, such as deforestation, urban areas usually spread gradually. Therefore, it is harder to determine two contrasted periods for stream flow time-series analysis. Hereafter, the time 
series of both disturbed and control catchments were divided into two sub-periods: the preurbanization period and the posturbanization period. The data time series of urban catchments (1940 to 2010) were divided into two sub-periods: the first and last 20 years of the time series, without gaps, are considered as preurbanization and posturbanization period respectively.

\subsection{Model residual approach}

In this study, we compared paired catchment analysis with the model residual approach. The model residual approach was slightly modified to mimic the paired catchment analysis (Fig. 2). It consists in basically replacing the control catchment with the simulation of the disturbed catchment itself using parameters calibrated on the preurbanization period to simulate discharge flow without the influence of increasing urban area. Given that the model parameters calibrated for the preurbanization period represent the nonurban behavior of the catchment. Then the discharge simulated with these parameters is the one that would have occurred in the urban catchment if urbanization had not increased. Thus, the differences between simulated and observed discharges for the period after urbanization are attributed to the effect of urbanization change on the hydrologic response.

Of course, this methodology relies heavily on the ability of the model's parameters to represent the catchment's nonurban conditions. Conversely, the model is not calibrated on the post-urbanization, only the observed flow data are used on the post-urbanization period. This avoids the problems of changing the model structure to fit the specificities of urban hydrological processes. Consequently, the rainfall-runoff model used in this study (the GR4J model, Fig. 3), is a conceptual daily four-parameter hydrological model developed mainly for rural catchments, requiring daily potential evapotranspiration and mean areal rainfall as inputs (Perrin et al., 2003). This model was applied on more than 1,000 catchments in France (Le Moine et al., 2007) and to hundreds of catchments from various countries (Australia, Brazil, Ivory Coast, Mexico, Great Britain, United States, etc.) with large gradients in terms of climate and geomorphological settings. 


\subsection{Model parameters calibration and uncertainty analysis}

To calibrate model parameters on each catchment, the Nash Sutcliffe Efficiency (NSE) coefficient (Nash and Sutcliffe, 1970), computed on the square root of discharge, was used as the objective function. This objective function was used since it provides a good trade-off between high and low flow simulations (Oudin et al., 2006). Since one of the objectives of the paper is to assess the impact of urbanization on a wide range of flows, this objective function appears more appropriate. If for other studies the methodology is applied to focus on a specific range of the flow values distribution, this objective function might certainly be modified to increase model efficiency on this specific range. The optimization procedure relies on a local search algorithm, steepest descent local-search procedure developed by Edijatno et al (1999). In this study, model parameter uncertainty was dealt with following a bootstrapping approach on the calibration years. The pre- and post-urbanization periods consist in the 20 first and last years of record respectively. The choice of the 20-year periods stems from a trade-off between two contradictory objectives: getting a calibration period of sufficient length to obtain reliable calibrated model parameters and getting two contrasted periods in terms of urbanization extent. The calibration of the rainfall runoff model was applied on a set of 15 years among the 20 available. The 15 years were drawn randomly from the 20 and this was performed 20 times, yielding to 20 sets of model parameters for each catchment on the pre-urbanization period. The 20 flow simulation records are then used for further analyses, allowing estimating uncertainty bounds on flow change estimation.

\subsection{Detection and quantification of flow changes due to urbanization}

Three flow characteristics were analyzed in this study in order to investigate the impact of urbanization for different flow conditions. The mean annual flow allows investigating the impact of urbanization on the catchment water balance.

Q05 and Q95 defined as the runoff exceeded 95\% and 5\% of the time respectively allow investigating the impact of urbanization on low flow and high flow values, respectively.

As in paired catchment studies, changes were detected in two steps. First, for paired catchment analysis, the linear relationships between the three annual flow components of 
the control and disturbed catchments were obtained for periods before and after urbanization. As for the model residual approach, linear relationships were obtained between observed flows and flows simulated by the model with parameters calibrated on the period before urbanization. Second, an analysis of covariance (ANCOVA) was performed to determine if the relationships between control and disturbed catchment flow characteristics (mean flow, Q05 and Q95) before and after urbanization were significantly different at the 0.1 level (Thomas and Megahan, 1998). The ANCOVA approach used in this paper consists in comparing two linear models: a full model (Equation 1) which incorporates individual slopes and intercepts for the two periods considered (before and after urbanization) and a completely reduced model (Equation 2) which incorporates only a single slope and intercept for the two periods.

$$
\begin{gathered}
\widehat{y_{l \jmath}}=\alpha_{1}+\beta_{1} x_{i 1}+\alpha_{2}+\beta_{2} x_{i 2} \\
\widehat{y_{\imath \jmath}}=\alpha+\beta x_{i j}
\end{gathered}
$$

Where $\widehat{y_{l j}}$ represent the predicted annual flow values of the disturbed catchment and $x_{i j}$ represent the annual flow values of the control catchment. In equation (1), it is understood that if the $i$ th annual flow value belongs to the period before urbanization, then $\alpha_{2}=0, \beta_{2}=0$ and $j=1$ in the subscript for $\widehat{y_{\imath j}}$ while $\alpha_{1}=0, \beta_{1}=0$ and $j=2$ in the subscript for $\widehat{y_{l j}}$ if the $i$ th annual flow value belongs to the period after urbanization.

The extra sum of squares principle (Draper and Smith, 1998) is then followed in order to detect if the flow values belonging to the two periods can be considered as same underlying distribution (null hypothesis). Basically, the test consists in assessing whether the regression sum of squares of the two models of equation (1) and (2) are significantly different. Note that based on the same principle, other hypotheses can be tested by considering model with different slopes but similar intercept and vice-versa. These complementary tests were not implemented to keep the presentation concise.

To quantify the changes for the three flow components, the method followed by Harr et al. (1975) was applied. It consists in computing the change based on differences between the regression equations obtained for pre- and posturbanization periods at a specific flow 
value for the control catchment. This specific flow value corresponds to the mean of the pre- and post-treatment means of flow for the control catchment (Fig. 4).

\section{Data}

\subsection{Hydroclimatic data}

The studied catchment set includes 43 US catchments composing 24 pairs of urban and nonurban catchments, five non-urban catchments being used twice for different urban catchments (Fig. 5). This catchment set was selected among the dataset of 9332 US catchments, with dataset from 1940 to 2010, of the Geospatial Attributes of Gages for Evaluating Streamflow version II (Falcone, 2011). The selection of the 24 pairs of catchments was dealt with the following two stages.

First, urban catchments were selected on the basis of the following criteria:

1. The percentage of urban areas must be greater than $15 \%$ in 2006 . This threshold was rather arbitrarily chosen and the literature review does not provide clear indications either on this threshold value or on the definition of a urban catchment. Note that a $15 \%$ of urban cover is also the threshold used in the UK to define a catchment as urban (Kjeldsen, 2010). This 15\% value might appear rather low but this allows getting a wide spectrum of intensity of urbanization. Besides, note that this threshold value is imposed at the first stage of the selection but it is rather the change in the percentage of urban area that is used hereafter for selecting the urban catchments and for analyzing their response to urbanization;

2. The estimated lag time between precipitation and runoff must be greater than 1 day since the rainfall-runoff model works at the daily time step and the hydroclimatic data were available at the daily time step. This unfortunately precludes the inclusion of small heavily urbanized catchments ;

3. The snow percent of total precipitation must be less than $20 \%$ since no snow routine was included within the rainfall-runoff model;

4. The number of years of flow record must be greater than 20 years for the period of 1940-1975 and greater than 20 years for the period 1985-2010. The rationale of the 20-years record period lies in a trade-off between the minimum length of 
record period to calibrate properly the hydrological model and the need to get relative independent sub-samples of 15-year records drawn among the 20-year calibration period, necessary to the uncertainty analysis performed;

5. The influence of dams and/or reservoirs should be minimal. We used the normal dam storage in catchment from the GAGES II database and imposed that this normal storage volume represent less than $10 \%$ of the mean annual flow.

This first selection leads to a database of 111 urban catchments out of 265 .

Second, the selection of the urbanized catchments was conditioned by the availability of a non-urban catchment in the vicinity of the urbanized catchment. The non-urban catchments were selected among the reference catchments of GAGES II that present less than $10 \%$ of urban areas and for which flow data are available for 20 concomitant years with the flow data of the paired urban catchment. The maximal distance between the centroids of the urban catchment and its paired non-urban catchment was set to $60 \mathrm{~km}$. Note that these criteria might yield several potential non-urban paired catchments for a given urban catchment. In these cases, we selected the non-urban catchment that was the most similar to the urban catchment on the basis of the strength of the linear relationship between annual flow values for the period before urbanization.

This selection procedure yields a set of 24 urban catchments and 19 non-urban catchments. Then, daily flow data were retrieved from the USGS stream gages database. Daily precipitation and air temperature data for each catchment were gathered from the database proposed by Livneh et al. (2013) based on the reanalysis method described by Maurer et al. (Maurer et al., 2002). This dataset consists in gridded daily meteorological data at the spatial resolution of $1 / 16^{\circ}$. Mean areal daily precipitation data were then computed on each catchment and mean areal daily potential evaporation were estimated from air temperature using a simple temperature-based potential evaporation formulation (Oudin et al., 2005). 


\subsection{Land use data and urban analysis}

Land use maps over the selected catchments were retrieved from the National Land Cover Database (NLCD) at a 30-m resolution, available for the years 1992, 2001 and 2006. The maps provide the information on the percentage of urban areas with imperviousness ranging from 20\% to $100 \%$ (Plasker, 2011). Since the 1992-2006 period is quite short compared to the available hydroclimatic time series, we used the housing density (HD) maps at a 90-m resolution as a proxy for urbanization to estimate long-term changes in urban areas. Housing density maps were developed by Theobald (2005) and were available from 1940 to 2010, every 10 years (Hammer et al., 2004).

The HD maps were provided with 14 classes and Theobald (2005) proposed some interpretation of this classes in terms of urbanization (area with more than 2 units per acre are considered urban areas). Urban areas derived from HD maps were found to match relatively well urban areas derived from historical satellite images and aerial photographs (Karstensen et al., 2013) In our study, we revisit the urban classes proposed by Theobald (2005) by comparing the HD maps to the NLCD maps. Instead of using a crisp conversion matrix between HD classes and the developed classes of NLCD, we fitted a fuzzy conversion matrix, i.e. each HD class is a composite of urban and non-urban areas (see Table 1). This may partially cope with the difference in terms of spatial resolution (30-m for the NLCD maps and 90-m for the HD maps). The approach involved first estimating the urban area from the NLCD of three existing maps (1992, 2001 and 2006) and the urban area for eight HD maps (1940, 1950, 1960, 1970, 1980, 1990, 2000 and 2010) over 628 catchments sampled from 9332 US catchments of the GAGES II database.

To estimate the urban area for 1940-2010 from the HD based on the NLCD maps (30-m resolution), we derived the conversion matrix by following five steps:

1. projecting the NLCD and HD maps for 628 catchments on a shared background to investigate their overlapping surface;

2. calculating the sum of the overlapping surface determined to be urban in the two maps; 
3. using cross-tabulation analysis as a contingency table analysis on the urban area data. A cross-tabulation is a two-dimensional table that records the number (frequency) of respondents that have the specific characteristics described in the cells of table;

4. calculating the fractions of the urban area overlapping between the NLCD and HD grids (Table. 1); and

5. using the fraction to multiply in the 1940-1990 HD grid and reconstructing urban areas at the same resolution as the NLCD maps.

The correlation of NLCD urban areas per catchment and reconstructed urban areas from HD maps was above 0.90 (Fig. 6) for 2006 and 2010, respectively (identical to 2001 and 2000 and 1992 and 1990), which was deemed acceptable to reconstruct urban change from 1940 to 2010 on the 24 catchment pairs.

Table 1. Conversion matrix to estimate urban area (in the sense of developed NLCD classes) from HD classes

\begin{tabular}{ccc}
\hline $\begin{array}{c}\text { HD Gridcode (unit par } \\
\text { acre) }\end{array}$ & $\begin{array}{c}\text { NLCD associated } \\
\text { urban fraction }\end{array}$ & $\begin{array}{c}\text { NLCD nonurban } \\
\text { percentage }\end{array}$ \\
\hline Undeveloped & 0.03 & 0.97 \\
$1 / 160<$ & 0.03 & 0.97 \\
{$[1 / 160,1 / 80]$} & 0.04 & 0.96 \\
{$[1 / 80,1 / 40]$} & 0.04 & 0.96 \\
{$[1 / 40,1 / 20]$} & 0.06 & 0.94 \\
{$[1 / 20,1 / 10$} & 0.09 & 0.91 \\
{$[1 / 10,1 / 5]$} & 0.16 & 0.84 \\
{$[1 / 5,1 / 1.7]$} & 0.34 & 0.66 \\
{$[1 / 1.6,2]$} & 0.67 & 0.33 \\
{$[2,5]$} & 0.88 & 0.12 \\
{$[5,10]$} & 0.93 & 0.07 \\
$>10$ & 0.93 & 0.07 \\
Industrial/commercial & 0.84 & 0.16 \\
Urban/regional parks & 0.1 & 0.99 \\
\hline
\end{tabular}

\subsection{Selected paired catchments}

The main characteristics of the paired catchments are summarized in Table 2. The urban change, i.e. the change in the fraction of urban area of the catchment was estimated using the reconstructed urban areas for the period 1940 to 2010, every 10 years and computed as the percentage of mean urban area of the 
posturbanization period minus the percentage of mean urban area of the preurbanization period. The urban change is generally up to $10 \%$ for the urbanized catchments and below 5\% for the nonurbanized catchments, these values are often taken as thresholds values by many authors (see e.g. Booth and Jackson, 1997; Schueler, 1994). The diversity of the urban change among the catchment set is particularly interesting since it allows investigating the relationship between the estimated flow changes and the urban change over the urbanized catchments. As described before, the paired catchments were selected on the basis of their spatial proximity and available concomitant data record periods, the distances between the centroids of the urbanized and nonurbanized catchments range from 11 to $55 \mathrm{~km}$, with median distance of $30 \mathrm{~km}$, which warrants a priori similar geomorphological settings. Besides, since flow variability due to land use or climate variability is often attenuated by the drainage areas of the catchments (Jones and Grant, 1996), we applied the MannWhitney test (Davis, 1986) to verify that the drainage areas of the two sets of urbanized and nonurbanized catchments were significantly similar ( $p$-value $>0.1$ ). 
Table 2. List of paired catchments and their main characteristics

\begin{tabular}{|c|c|c|c|c|c|c|}
\hline $\begin{array}{c}\text { Catchment code } \\
\text { (urbanized/nonurbanized) }\end{array}$ & States & $\begin{array}{c}\text { Centroid } \\
\text { distance } \\
(\mathrm{km})\end{array}$ & Area $\left(\mathrm{km}^{2}\right)$ & $\begin{array}{l}\text { Preurban } \\
\text { period }\end{array}$ & $\begin{array}{c}\text { Posturban } \\
\text { period }\end{array}$ & $\begin{array}{c}\text { Urban } \\
\text { change }(\%)\end{array}$ \\
\hline 01481000/01491000* & Pennsylvania/Maryland & 46.0 & $755.2 / 292.0$ & $1948-1976$ & $1991-2010$ & $31 / 5$ \\
\hline 01481500/01491000 & Delaware/Maryland & 45.3 & $824.0 / 292.0$ & $1948-1967$ & $1991-2010$ & $31 / 5$ \\
\hline 01571500/01568000 & Pennsylvania/Pennsylvania & 16.1 & $557.7 / 534.4$ & $1954-1974$ & $1991-2010$ & $16 / 3$ \\
\hline 01616500/01632900 & West Virginia/Virginia & 54.6 & $706.4 / 245.0$ & $1960-1980$ & $1991-2010$ & $11 / 6$ \\
\hline 01619500/01644000 & Maryland/Virginia & 28.2 & $728.4 / 267.2$ & $1947-1967$ & $1991-2010$ & $14 / 4$ \\
\hline $01643500 / 01662800$ & Maryland/Virginia & 21.4 & $163.8 / 267.2$ & $1948-1976$ & $1991-2010$ & $28 / 1$ \\
\hline $01646000 / 01662800$ & Virginia/Virginia & 38.0 & $149.9 / 267.2$ & $1947-1967$ & $1991-2010$ & $75 / 1$ \\
\hline $02042500 / 02046000$ & Virginia/Virginia & 31.2 & $646.9 / 288.5$ & $1946-1966$ & $1991-2010$ & $27 / 1$ \\
\hline 02055000/02018000 & Virginia/Virginia & 13.5 & $996.6 / 852.3$ & $1940-1959$ & $1991-2010$ & $10 / 2$ \\
\hline 02056000/03170000 & Virginia/Virginia & 18.3 & 1323.0/794.6 & $1940-1959$ & $1991-2010$ & $13 / 1$ \\
\hline 02165000/02192500 & outh Carolina/South Carolina & 22.1 & $611.3 / 555.9$ & $1940-1959$ & $1968-2004$ & $21 / 2$ \\
\hline $02233500 / 02312200$ & Florida/Florida & 41.2 & $678.2 / 413.5$ & $1958-1978$ & $1991-2010$ & $27 / 1$ \\
\hline $02310000 / 02312200$ & Florida/Florida & 31.8 & $177.6 / 413.5$ & $1958-1978$ & $1991-2010$ & $21 / 1$ \\
\hline $03118000 / 03140000$ & Ohio/Ohio & 36.1 & $116.2 / 70.3$ & $1941-1961$ & $1991-2010$ & $16 / 0$ \\
\hline $03289500 / 03285000$ & Kentucky/Kentucky & 32.4 & $1221.3 / 822.3$ & $1942-1962$ & $1991-2010$ & $10 / 3$ \\
\hline $03293000 / 03368000$ & Kentucky/Indiana & 43.2 & $48.8 / 29.7$ & $1955-1975$ & $1991-2010$ & $47 / 0$ \\
\hline $03352500 / 03340800$ & Indiana/Indiana & 49.6 & $772.2 / 357.6$ & $1957-1977$ & $1991-2010$ & $13 / 0$ \\
\hline 03362000/03340800 & Indiana/Indiana & 39.6 & $260.4 / 357.6$ & 1957-1977 & $1991-2010$ & $9 / 0$ \\
\hline $03433500 / 03427500$ & Tennessee/Tennessee & 32.2 & $1055.7 / 677.4$ & $1951-1975$ & $1982-2008$ & $13 / 1$ \\
\hline $03451500 / 03465500$ & North Carolina/Tennessee & 34.6 & $2444.7 / 2081.6$ & $1940-1959$ & $1991-2010$ & $23 / 5$ \\
\hline $03453500 / 03465500$ & North Carolina/Tennessee & 30.3 & $3448.5 / 2081.6$ & $1942-1962$ & $1991-2010$ & $19 / 5$ \\
\hline 07195000/07197000 & Arkansas/Oklahama & 26.3 & $335.6 / 808.4$ & $1950-1970$ & $1971-2010$ & $20 / 1$ \\
\hline $12080010 / 12025000$ & Washignton/Washignton & 11.3 & $401.7 / 404.9$ & $1945-1965$ & $1991-2010$ & $10 / 2$ \\
\hline $12108500 / 12145500$ & Washignton/Washignton & 13.7 & $71.1 / 79.0$ & 1945-1970 & 1991-2010 & $17 / 4$ \\
\hline
\end{tabular}




\section{Results and discussion}

The results are presented in the following order: (i) basic information on the setting of the paired and model residual approaches, (ii) trend detection and amount of change estimated by the paired catchment approach and (iii) comparison of the amount of changes estimated by the paired and model residual approaches. For each sub-section, the results are first illustrated on one pair of catchments and second synthetically presented for the whole set of 24 pairs of catchments.

The exemplar pair of catchments is composed by the Brandywine Creek at Chadds Ford in Pennsylvania (USGS code 01481000) as the urbanized catchment and the Choptank River near Greensboro in Maryland (USGS code 01491000) as the nonurbanized catchment. Fig. 7 shows the observed mean flow, Q95 and Q05 annual time series on the record period for both catchments. As for the other pairs, the annual flow variations for the two catchments are in good agreement due to the mostly similar climatic settings of the two neighbor catchments.

\subsection{Paired and model residual basic information analysis}

The success of both paired and model residual approaches in detecting and quantifying changes in the hydrological response due to land use changes depends on the validity of the different steps of the methodology. The first step concerns the significance of the linear relationships linking the response of the catchments constituting each pair. As mentioned above, these linear equations are derived for the three flow components (mean annual flow, annual Q95 and annual Q05) and for the periods before and after urbanization:

- Linear regression of paired catchment analysis. In this step the relationship between the annual flows of the control and disturbed catchments is investigated.

- Linear regression of model residual analysis. In this step the relationship between the simulated and observed flows on the disturbed catchment is investigated.

To this aim, the validity of the linear regression relationships was determined by analyzing the coefficients of determination $\left(\mathrm{R}^{2}\right)$. Fig.8 shows the distributions of the corresponding coefficients of determination $\mathrm{R}^{2}$ for the three annual flow components over 
the preurbanization periods. The median $\mathrm{R}^{2}$ values for both approaches and for the three flow components are generally greater than 0.6, which was deemed satisfactory. Note that linear relationships on Q05 are generally less satisfying than for the mean flow and Q95. Besides, the model residual approach performs slightly better than the paired catchment approach, which is probably due to the fact that the model residual approach relies on the simulation of a calibrated hydrological model.

The NSE values calculated across the 24 urbanized catchments before urbanization showed that there was generally good fit (median NSE greater than 0.75 and the $5^{\text {th }}$ and $95^{\text {th }}$ percentiles, 0.64 and 0.87 , respectively), which confirms the ability of the model to capture the hydrologic response of the urbanized catchment before urbanization (Table $3)$.

\subsection{Trend and change detection results (paired approach)}

Changes in the hydrological response of paired catchments after urbanization were calculated as differences between disturbed and control catchment flows. The ANCOVA method, involving simple linear regression equations was used to detect significant flow changes in the 24 paired catchments. Fig. 9 shows the results for the exemplar paired catchments and for the Q05 flow component. For this pair of catchments, the regression on Q05 obtained for the posturbanization period was found significantly different from the regression equation obtained for the preurbanization period ( $p$-value $=0.01$ ). Moreover, the mean change was computed using the two regression equations: the value of this change is negative: $-0.073 \mathrm{~mm} / \mathrm{d}$, corresponding to a relative flow change of -16 $\%$. Consequently, on this catchment, it can be concluded from the paired catchment analysis that urbanization is responsible for a significant decrease in Q05.

The same analysis was performed for all the other pairs of catchments and for the three flow components of the hydrologic response. Then the computed flow changes attributed to urbanization were compared to the urban change of the urbanized catchment. The results for the 24 pairs of catchments are shown in Fig. 10. 
In general, mean flow and Q95 are increased (16/24 and 18/24, respectively), but the amount of change cannot be easily explained by the urban area change. Concerning Q05, the changes can be either positive or negative, without any apparent link to the extent of urbanization. This might result from Q05 being impacted by several factors such as ground water networks and sewer systems, which are not taken into account in the simple metric of urbanization used in this study. Consequently, more information on the urbanization type is required to understand the processes affecting low flows in urbanized catchments and it could be a challenge for future study.

\subsection{Comparison of paired and model residual approaches}

This section compares the results obtained by the paired catchment and the model residual approaches. As explained above, the methodology developed for applying the model residual approach allows us to compare the results of the two approaches in a rather straightforward way.

Consequently, similar to what was done for paired catchment analysis, changes in the hydrologic response for model residual analysis were detected by ANCOVA and the quantification of changes was computed using the two regression equations obtained for the periods before and after urbanization. Fig. 11 shows the linear relationships obtained with the model residual approach on Q05 for the urbanized catchment (the Brandywine Creek at Chadds Ford, code 01481000 ) already taken as an example for presenting the results of the paired catchment approach. As for paired catchment analysis in this particular case, the Q05 significantly decreased of about $0.063 \mathrm{~mm} / \mathrm{d}$ between the two periods $(p$-value $=0.041)$, corresponding to a relative flow change of $-13 \%$, which is relatively similar to the change quantified by paired catchment analysis $(-16 \%)$.

Model residual analysis was performed on the set of 24 urbanized catchments and the comparison of changes detected by paired catchment analysis and model residual analysis are shown in Fig. 12. As explained in Section 2.3, uncertainty analysis was estimated by calibrating model parameter values on 20 different subperiods, uncertainty bounds derived from the multiple parameter sets are plotted as uncertainty bars in Fig. 12.

Generally speaking, the relative changes in flow components detected by model residual analysis are in good agreement with the changes obtained following paired catchment 
analysis. Besides, nonsignificant changes $(\mathrm{p}>0.1)$ found in catchments' flow characteristics are generally the same for the paired and model residual approaches. Note that the model residual approach tends to estimate lower changes in flow characteristics compared to the paired catchment approach. This may stems from hydrological model uncertainties and in particular the choice of the objective function that yields in general smoother hydrographs compared to observations and thus the changes are underestimated but the dataset is too limited to analyze this result in more details. As shows in Table 3, for the mean flow and Q95, there are 50\% and 54\% against $42 \%$ and $58 \%$ significant changes in alternative and paired approach respectively. For Q05 there are 58\% and 70\% significant changes in alternative approach and paired catchment ( $\mathrm{p}$-values less than 0.1).

To shed more lights on the cases for which the two approaches provide rather different flow changes estimates, Table 3 synthesizes the results and indicates the main characteristics of the both approaches. It seems difficult to draw robust conclusions on this Table since the differences may stem from multiple reasons. Small distances between paired catchments and relatively good flow simulations seem to increase the agreements between the two approaches but the catchment set is too limited to provide practical guidelines to choose the more appropriate method on a given catchment. 
Table 3.Summary of the hydrological characteristics for Paired catchments and residual model

\begin{tabular}{|c|c|c|c|c|c|c|c|c|c|}
\hline \multirow{2}{*}{ BV_URB } & \multirow{2}{*}{ BV_REF } & \multirow{2}{*}{ Delta_urb } & \multicolumn{2}{|c|}{ Q05 change } & \multicolumn{2}{|c|}{ Q95 change } & \multicolumn{2}{|c|}{ Mean flow change } & \multirow{2}{*}{$\begin{array}{c}\text { Model } \\
\text { NSE }\end{array}$} \\
\hline & & & Paired & Model & Paired & Model & Paired & Model & \\
\hline 01481000 & 01491000 & 31 & -16. & -13. & 18. & 2. & -2 & -7 & 0.78 \\
\hline 01481500 & 01491000 & 31 & -7 & -3 & 10 & -11 & 0 & $-12^{*}$ & 0.70 \\
\hline 01571500 & 01568000 & 16 & -4 & -3 & 7. & -12 & 5 & $-9 *$ & 0.74 \\
\hline 01616500 & 01632900 & 11 & 17. & 13 & 6 & 5 & 7 & 5 & 0.65 \\
\hline 01619500 & 01644000 & 14 & $17^{* *}$ & 6. & 7 & $-17^{* *}$ & 6 & $-12^{*}$ & 0.77 \\
\hline 01643500 & 01662800 & 28 & -11 & -9 & 14 & 5. & 5 & 0 & 0.74 \\
\hline 01646000 & 01583500 & 75 & $-20 * *$ & -2 & $34^{* *}$ & $34^{* * *}$ & 23 & 9 & 0.87 \\
\hline 02042500 & 02046000 & 27 & $11^{* * *}$ & $-4^{* *}$ & $22^{* *}$ & -4 & 11. & -1 & 0.80 \\
\hline 02055000 & 02018000 & 10 & -10 & -13 & -5 & -7 & -5 & -8 & 0.70 \\
\hline 02056000 & 03170000 & 13 & $17^{* *}$ & 11 & 12. & -3 & $9 *$ & -2 & 0.67 \\
\hline 02165000 & 02192500 & 21 & $213^{* *}$ & $196^{* *}$ & $16^{*}$ & & $24 * * *$ & $12^{* * *}$ & 0.68 \\
\hline 02233500 & 02312200 & 27 & $67^{* * *}$ & $41 * * *$ & 16. & -2 & $38 * *$ & 16. & 0.83 \\
\hline 02310000 & 02312200 & 21 & $-5^{* *}$ & $-10 * *$ & -11 & -13 & -13 & -14 & 0.72 \\
\hline 03118000 & 03140000 & 16 & 14 & 39 & $44 * * *$ & 9 & $50 * * *$ & $17^{*}$ & 0.70 \\
\hline 03289500 & 03285000 & 10 & $122^{* *}$ & $139 * *$ & 10 & 4 & 12. & 10. & 0.85 \\
\hline 03293000 & 03368000 & 47 & $-47^{*}$ & $-48^{*}$ & 9 & 4 & 1 & -1 & 0.66 \\
\hline 03352500 & 03340800 & 13 & 2. & -16 & 11. & 0 & 15. & -2 & 0.75 \\
\hline 03362000 & 03340800 & 9 & $122 * *$ & $74 * *$ & $25^{* *}$ & -3 & $33^{* * *}$ & 9 & 0.60 \\
\hline 03433500 & 03427500 & 13 & & 26 & 0 & $-11^{* *}$ & 11. & -5 & 0.89 \\
\hline 03451500 & 03465500 & 23 & 8. & 0 & 5. & -2 & 2 & -2 & 0.86 \\
\hline 03453500 & 03465500 & 19 & 7 & -2 & 7. & 0 & 1 & -3 & 0.87 \\
\hline 07195000 & 07197000 & & $44^{* *}$ & $67^{* * *}$ & 30. & $26^{* *}$ & 25. & $34^{* *}$ & 0.64 \\
\hline 12080010 & 12025000 & 10 & $-15^{*}$ & -7. & $0 *$ & 3. & -2 & $3 *$ & 0.86 \\
\hline 12108500 & 12145500 & 17 & -4 & $-15^{* *}$ & 1 & -1 & 1 & -5. & 0.85 \\
\hline
\end{tabular}

"." Is the p-value $<0.1$, "*” $p<0.01$, “**” $p<0.001$, “***" $p<0.001$

Nash Sutcliffe Efficiency (NSE): The ability of the hydrological model with its model parameters to simulate the stream flow

\section{Conclusion}

This paper investigates potential changes in flow, resulting from the transformation of previously rural landscapes into urban areas at the catchment scale. While the paired catchment approach is deemed to provide a robust method to detect the effect of land use changes on the catchment's flow characteristics, this approach is usually limited by the availability of two neighbor catchments with and without land use change but under 
similar climate conditions. An alternative approach involving hydrological modeling is therefore often followed, but it presents well-known caveats that are difficult to assess. The aim of this paper was to compare these two approaches in terms of detecting and quantifying the impact of urbanization on three annual flow characteristics. Historical urban development was reconstituted using house density maps as a proxy of urbanization. The main originality of this study stems from this comparison framework and the relatively large sample of 24 urbanized (and paired nonurbanized) catchments.

The first major result of this study is that the two approaches are generally in relative good agreement in terms of detection and quantification of changes for the three flow characteristics analyzed (mean annual flow, annual Q95 and annual Q05). This is a reassuring result since data requirements often make it impossible to apply the paired catchment approach. It should be noted that a daily hydrological model was used in this study so that the impact of urbanization could be assessed based on more extreme values such as daily flow percentiles, which is seldom possible for the paired catchment studies since it requires very close neighbor catchments. The differences between the two approaches observed on some catchments may stem from the several uncertainties for each approach. These uncertainties were quantified partially for the model residual approach by taking into account parameter uncertainty during the model calibration process. As for the paired catchment approach, the uncertainties classically originate from the dissimilarities of the paired catchments in terms of environmental settings. From the analysis performed in this study, we were not able to find which of these uncertainties explain at the first order the observed differences between flow changes estimates. Further research is needed on this issue by considering additional catchments.

The second notable result of the study is that the impact of urbanization on the catchment's hydrologic response is difficult to generalize: the proportion of nonsignificant trends, significantly increasing trends and significantly decreasing trends are on the same order of magnitude, even if an increase in urban areas generally has a greater impact on mean flow and Q95 than on Q05. Nevertheless, the estimated changes in this study's catchments could not be related only to urban change. Our sample of catchments is limited to 24 paired catchments because of the data requirements of the 
paired catchment study. Following the model residual approach allows a larger number of urbanized catchments, which could increase the statistical relevance of the results and allow investigating in more details which landscape modifications of urbanization affect more the catchment flows.

It should be noted that the control (nonurban) catchments were selected only on the basis of urban development (urban fraction of the total drainage area). However, the flow characteristics might also change due to other land use changes (e.g., agriculture, forestry, etc.) than urbanization. Ideally, we should take all land-use change information into account when selecting the control catchments (Salavati et al., 2015c).

The contrasting results of the impact of urbanization on hydrology could be partially due to the difficulty of characterizing urbanization quantitatively and even qualitatively. The commonly used urban area fraction and/or mean areal imperviousness may not be able to explain the changes in the catchment hydrologic response due to urbanization. Other local anthropogenic changes (dams, sewer system network, geomorphological changes of streams, etc.) may also have a significant impact on the catchment hydrology. More researches are also needed to better understand of geometric properties and spectral diversity of impervious surfaces over time (Wang and Hejazi, 2011).

Additionally, it is important to consider the scale at which an urban area has a greater impact on the catchment hydrologic response. These results suggest that more detailed urban typologies are necessary to explain the various impacts of urbanization on catchment responses. Further research will focus on the use of other urbanization metrics to understand the variability of the hydrological impacts of urbanization. These metrics may be landscape metrics and/or metrics taking into account the connectivity of urban areas to the hydrography network.

\section{Acknowledgements}

The funding support for this study came from the Campus France. This study utilizes data from several sources. Daily streamflow were collected from the USGS website 
(available at http://waterdata.usgs.gov/). The newer 1/16 degree daily rainfall and temperature gridded data beginning in 1915 (see (Livneh et al., 2013)) are available from ftp://ftp.hydro.washington.edu/pub/blivneh/CONUS/

Geospatial data and classifications for stream gages maintained by the U.S. Geological Survey (USGS) termed Gages II are available from http://water.usgs.gov/lookup/getspatial?gagesII_Sept2011.

National Land Cover Database (NLCD) data were obtained from the Multi-Resolution Land Characteristics (MRLC) Consortium website (available at http://www.mrlc.gov/about.php). House Density data were collected in 2014 from the SILVIS Lab, Spatial Analysis for Conservation and Sustainability (available at http://silvis.forest.wisc.edu/old/Library/HousingDataDownload.php?state=United\%20Sta tes\&abrev=US). We would also like to thank David Theobald and Thomas Over for their help about House Density data.

\section{Reference List}

Andréassian, V., 2004. Waters and forests: from historical controversy to scientific $\begin{array}{llll}\text { debate. Journal of Hydrology, 291(1-2): } & \text { 1-27. }\end{array}$ DOI:http://dx.doi.org/10.1016/j.jhydrol.2003.12.015

Andréassian, V., Parent, E., Michel, C., 2003. A distribution-free test to detect gradual changes in watershed behavior. Water Resour Res, 39(9): 1252. DOI:10.1029/2003wr002081

Barringer, T.H., Reiser, R.G., Price, C.V., 1994. Potential effects of development on flow characteristics of two new jersey streams1

JAWRA Journal of the American Water Resources Association, 30(2): 283-295. DOI:10.1111/j.1752-1688.1994.tb03291.x

Blöschl, G. et al., 2007. At what scales do climate variability and land cover change impact on flooding and low flows? Hydrol Process, 21(9): 1241-1247. DOI:10.1002/hyp.6669

Booth, D.B., Jackson, C.R., 1997. Urbanization of aquatic systems: Degradation thresholds, stormwater detection and the limits of mitigation 1. J Am Water Resour As, 33(5): 1077-1090.

Bowling, L.C., Storck, P., Lettenmaier, D.P., 2000. Hydrologic effects of logging in western Washington, United States. Water Resour Res, 36(11): 3223-3240.

Brandes, D., Cavallo, G.J., Nilson, M.L., 2005. Base flow trends in urbanizing watersheds of the Delaware River basin. J Am Water Resour As, 41(6): 13771391. DOI:10.1111/j.1752-1688.2005.tb03806.x

Brath, A., Montanari, A., Moretti, G., 2006. Assessing the effect on flood frequency of land use change via hydrological simulation (with uncertainty). Journal of 
Hydrology,

$324(1-4)$ :

141-153.

DOI:http://dx.doi.org/10.1016/j.jhydrol.2005.10.001

Braud, I., Fletcher, T.D., Andrieu, H., 2013. Hydrology of peri-urban catchments: Processes and modelling. Journal of Hydrology, 485: 1-4. DOI:http://dx.doi.org/10.1016/j.jhydrol.2013.02.045

Bronstert, A., Niehoff, D., Bürger, G., 2002. Effects of climate and land-use change on storm runoff generation: present knowledge and modelling capabilities. Hydrol Process, 16(2): 509-529. DOI:10.1002/hyp.326

Changnon, S.A., Demissie, M., 1996. Detection of changes in streamflow and floods resulting from climate fluctuations and land use-drainage changes. Climatic Change, 32(4): 411-421.

Claessens, L., Hopkinson, C., Rastetter, E., Vallino, J., 2006. Effect of historical changes in land use and climate on the water budget of an urbanizing watershed. Water Resour Res, 42(3).

Davis, J.C., 1986. Statistics and data analysis in geology. John Wiley \& Sons, pp. 103105.

De Roo, A., Odijk, M., Schmuck, G., Koster, E., Lucieer, A., 2001. Assessing the effects of land use changes on floods in the meuse and oder catchment. Physics and Chemistry of the Earth, Part B: Hydrology, Oceans and Atmosphere, 26(7-8): 593-599. DOI:http://dx.doi.org/10.1016/S1464-1909(01)00054-5

DeWalle, D.R., Swistock, B.R., Johnson, T.E., McGuire, K.J., 2000. Potential effects of climate change and urbanization on mean annual streamflow in the United States. Water Resour Res, 36(9): 2655-2664. DOI:10.1029/2000wr900134

Draper, N.R., Smith, H., 1998. Extra sums of squares and tests for several parameters being zero. Applied Regression Analysis, Third Edition: 149-51.

Edijatno, De Oliveira Nascimento, N., Yang, X., Makhlouf, Z., Michel, C., 1999. GR3J: a daily watershed model with three free parameters. Hydrological Sciences Journal, 44(2): 263-277. DOI:10.1080/02626669909492221

Falcone, J., 2011. GAGES-II: Geospatial Attributes of Gages for Evaluating Streamflow, Reston, VA.

FitzHugh, T.W., Vogel, R.M., 2011. The impact of dams on flood flows in the United States. River Research and Applications, 27(10): 1192-1215. DOI:10.1002/rra.1417

Geiger, W.F., Marsalek, J., Rawls, W.J., Zuidema, F.C., 1987. Manual on drainage in urbanized areas, Volume I: Planning and design of drainage systems. UNESCO, Belgium.

Hammer, R.B., Stewart, S.I., Winkler, R., Radeloff, V.C., Voss, P.R., 2004. Characterizing spatial and temporal residential density patterns across the U.S. Midwest, 1940-1990. Landscape Urban Plan, 69 183-199.

Harr, R.D., Harper, W.C., Krygier, J.T., Hsieh, F.S., 1975. Changes in storm hydrographs after road building and clear-cutting in the Oregon Coast Range. Water Resour Res, 11(3): 436-444. DOI:10.1029/WR011i003p00436

Harrigan, S., Murphy, C., Hall, J., Wilby, R.L., Sweeney, J., 2014. Attribution of detected changes in streamflow using multiple working hypotheses. Hydrol. Earth Syst. Sci., 18(5): 1935-1952. DOI:10.5194/hess-18-1935-2014 
Hejazi, M.I., Moglen, G.E., 2008. The effect of climate and land use change on flow duration in the Maryland Piedmont region. Hydrol Process, 22(24): 4710-4722. DOI:10.1002/hyp.7080

Homa, E.S., Brown, C., McGarigal, K., Compton, B.W., Jackson, S.D., 2013. Estimating hydrologic alteration from basin characteristics in Massachusetts. Journal of Hydrology, 503(0): 196-208. DOI:http://dx.doi.org/10.1016/j.jhydrol.2013.09.008

Hundecha, Y., Bárdossy, A., 2004. Modeling of the effect of land use changes on the runoff generation of a river basin through parameter regionalization of a watershed model. Journal of Hydrology, 292(1-4): 281-295. DOI:http://dx.doi.org/10.1016/j.jhydrol.2004.01.002

Jacobson, C.R., 2011. Identification and quantification of the hydrological impacts of imperviousness in urban catchments: A review. Journal of Environmental Management, $92(6)$ : 1438-1448. DOI:http://dx.doi.org/10.1016/j.jenvman.2011.01.018

Jones, J.A., Grant, G.E., 1996. Peak Flow Responses to Clear-Cutting and Roads in Small and Large Basins, Western Cascades, Oregon. Water Resour Res, 32(4): 959-974. DOI:10.1029/95wr03493

Karstensen, K., Shaver, D., Alexander, R., Over, T., Soong, D.T., 2013. Land change in the Central Corn Belt Plains Ecoregion and hydrologic consequences in developed areas: 1939-2000. 2013-1157, Reston, VA.

Kauffman, G., Belden, A., Vonck, K., Homsey, A., 2009. Link between Impervious Cover and Base Flow in the White Clay Creek Wild and Scenic Watershed in Delaware. Journal of Hydrologic Engineering, 14(4): 324-334.

Kjeldsen, T.R., 2010. Modelling the impact of urbanization on flood frequency relationships in the UK. Hydrology Research, 41(5): 391-405.

Konrad, C.P., Booth, D.B., 2005. Hydrologic changes in urban streams and their ecological significance. Am Fish S S, 47: 157-177.

Kuczera, G., Raper, G.P., Brah, N.S., Jayasuriya, M.D., 1993. Modelling yield changes after strip thinning in a mountain ash catchment: an exercise in catchment model validation. Journal of Hydrology, 150(2-4): 433-457. DOI:http://dx.doi.org/10.1016/0022-1694(93)90120-X

Le Moine, N., Andréassian, V., Perrin, C., Michel, C., 2007. How can rainfall-runoff models handle intercatchment groundwater flows? Theoretical study based on 1040 French catchments. Water Resour Res, 43: W06428. DOI:citeulike-articleid: 1554155

doi: 10.1029/2006wr005608

Li, Z., Liu, W.-Z., Zhang, X.-c., Zheng, F.-1., 2009. Impacts of land use change and climate variability on hydrology in an agricultural catchment on the Loess Plateau of China. Journal of Hydrology, 377(1-2): 35-42. DOI:http://dx.doi.org/10.1016/j.jhydrol.2009.08.007

Livneh, B. et al., 2013. A Long-Term Hydrologically Based Dataset of Land Surface Fluxes and States for the Conterminous United States: Update and Extensions. Journal of Climate, 26(23): 9384-9392. DOI:10.1175/jcli-d-12-00508.1

Lørup, J.K., Refsgaard, J.C., Mazvimavi, D., 1998. Assessing the effect of land use change on catchment runoff by combined use of statistical tests and hydrological modelling: case studies from Zimbabwe. Journal of Hydrology, 205: 147-163. 
Maurer, E.P., Wood, A.W., Adam, J.C., Lettenmaier, D.P., Nijssen, B., 2002. A LongTerm Hydrologically Based Dataset of Land Surface Fluxes and States for the Conterminous United States. Journal of Climate, 15(22): 3237-3251. DOI:http://dx.doi.org/10.1175/JCLI-D-12-00508.1

McIntyre, N. et al., 2014. Modelling the hydrological impacts of rural land use change. Hydrology Research, 45(6): 737-754.

Meyer, S.C., Wilson, S.D., 2002. Impact of urbanization on base flow and recharge rates, northeastern Illinois: Summary of year 1 activities, Proceedings of the Annual IGC Conference. Illinois Groundwater Consortium, pp. 27-29.

Miller, J.D. et al., 2014. Assessing the impact of urbanization on storm runoff in a periurban catchment using historical change in impervious cover. Journal of Hydrology, 515(0): 59-70. DOI:http://dx.doi.org/10.1016/j.jhydrol.2014.04.011

Motta, J.C., Tucci, C.E.M., 1984. Simulation of the urbanization effect in flow. Hydrological Sciences Journal, 29(2): 131-147. DOI:10.1080/02626668409490930

Nash, J.E., Sutcliffe, J.V., 1970. River flow forecasting through conceptual models. Part I - a discussion of principles. Journal of Hydrology, 10: 282-290.

Niehoff, D., Fritsch, U., Bronstert, A., 2002. Land-use impacts on storm-runoff generation: scenarios of land-use change and simulation of hydrological response in a meso-scale catchment in SW-Germany. Journal of Hydrology, 267(1-2): 8093. DOI:http://dx.doi.org/10.1016/S0022-1694(02)00142-7

Oudin, L., Andréassian, V., Mathevet, T., Perrin, C., Michel, C., 2006. Dynamic averaging of rainfall-runoff model simulations from complementary model parameterization. Water Resour Res, 42(7): W07410.

Oudin, L. et al., 2005. Which potential evapotranspiration input for a lumped rainfallrunoff model?: Part 2 Towards a simple and efficient potential evapotranspiration model for rainfall-runoff modelling. Journal of Hydrology, 303(1-4): 290-306. DOI:http://dx.doi.org/10.1016/j.jhydrol.2004.08.026

Perrin, C., Michel, C., Andréassian, V., 2003. Improvement of a parsimonious model for streamflow simulation. Journal of Hydrology, 279: 275-289.

Plasker, J.R., 2011. National landcover database 2006. Photorammetric Engineering \& Remote Sensing, 77(9): 855-864.

Prosdocimi, I., Kjeldsen, T., Miller, J., 2015. Detection and attribution of urbanization effect on flood extremes using nonstationary flood frequency models. Water Resour Res.

Rose, S., Peters, N.E., 2001. Effects of urbanization on streamflow in the Atlanta area (Georgia, USA): a comparative hydrological approach. Hydrol Process, 15(8): 1441-1457.

Rougé, C., Cai, X., 2014. Crossing-Scale Hydrological Impacts of Urbanization and Climate Variability in the Greater Chicago Area. Journal of Hydrology, 517: 1327. DOI:10.1016/j.jhydrol.2014.05.005

Rozell, D.P.E., 2010. Urbanization and Trends in Long Island Stream Base Flow, Seventeenth Annual Conference on Geology of Long Island and Metropolitan, New York, pp. 12. 
Salavati, B., Oudin, L., Furusho, C., Ribstein, P., 2015c. Analysing the impact of urban areas patterns on the mean annual flow of 43 urbanized catchments. Proc. IAHS, 370: 29-32. DOI:10.5194/piahs-370-29-2015

Salvadore, E., Bronders, J., Batelaan, O., 2015. Hydrological modelling of urbanized catchments: A review and future directions. Journal of Hydrology, 529, Part 1: 62-81. DOI:http://dx.doi.org/10.1016/j.jhydrol.2015.06.028

Schreider, S.Y. et al., 2002. Detecting changes in streamflow response to changes in nonclimatic catchment conditions: farm dam development in the Murray-Darling basin, Australia. Journal of Hydrology, 262: 84-98.

Schueler, T., 1994. The importance of imperviousness. Watershed Protection Techniques, 3: $1-12$.

Seibert, J., McDonnell, J.J., 2010. Land-cover impacts on streamflow: a change-detection modelling approach that incorporates parameter uncertainty. Hydrological Sciences Journal, 55(3): 316-332. DOI:10.1080/02626661003683264

Shaw, M.E., 1994. Hydrology in practice. In: 3rd (Ed.). Chapman \& Hall, London, pp. 569.

Shuster, W., Bonta, J., Thurston, H., Warnemuende, E., Smith, D., 2005. Impacts of impervious surface on watershed hydrology: A review. Urban Water Journal, 2(4): 263-275.

Siriwardena, L., Finlayson, B.L., McMahon, T.A., 2006. The impact of land use change on catchment hydrology in large catchments: The Comet River, Central Queensland, Australia. Journal of Hydrology, 326(1-4): 199-214. DOI:http://dx.doi.org/10.1016/j.jhydrol.2005.10.030

Theobald, D.M., 2005. Landscape patterns of exurban growth in the USA from 1980 to 2020. Ecol Soc, 10(1).

Thomas, R.B., Megahan, W.F., 1998. Peak flow responses to clear-cutting and roads in small and large basins, Western Cascades, Oregon: A second opinion. Water Resour Res, 34(12): 3393-3403. DOI:10.1029/98wr02500

Wagener, T., 2007. Can we model the hydrological impacts of environmental change? Hydrol Process, 21(23): 3233-3236. DOI:10.1002/hyp.6873

Wang, D., Hejazi, M., 2011. Quantifying the relative contribution of the climate and direct human impacts on mean annual streamflow in the contiguous United States. Water Resour Res, 47(10): 1-16. DOI:10.1029/2010WR010283

Weng, Q., 2012. Remote sensing of impervious surfaces in the urban areas: Requirements, methods, and trends. Anglais, 117: 34-49.

Yang, L. et al., 2013. Urbanization and Climate Change: An Examination of Nonstationarities in Urban Flooding. J Hydrometeorol, 14(6): 1791-1809. DOI:10.1175/jhm-d-12-095.1

Zégre, N., Skaugset, A.E., Som, N.A., McDonnell, J.J., Ganio, L.M., 2010. In lieu of the paired catchment approach: Hydrologic model change detection at the catchment scale. Water Resour Res, 46(11): W11544. DOI:10.1029/2009wr008601

Zhou, F. et al., 2013. Hydrological response to urbanization at different spatio-temporal scales simulated by coupling of CLUE-S and the SWAT model in the Yangtze River Delta region. Journal of Hydrology, 485(0): 113-125. DOI:http://dx.doi.org/10.1016/j.jhydrol.2012.12.040 


\section{Tables}

Table 1. Conversion matrix to estimate urban area (in the sense of developed NLCD

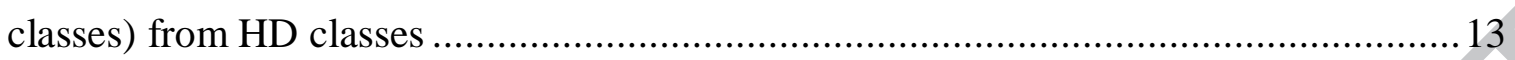

Table 2. List of paired catchments and their main characteristics .......................... 15 Table 3.Summary of the hydrological characteristics for Paired catchments and residual

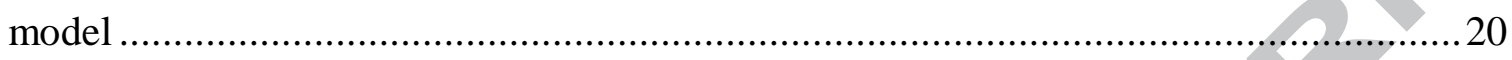


Fig. 1. Scheme of paired catchment analysis using flow observations. . P is precipitation, PE: evapotranspiration and XPRE model parameters for preurbanisation period Fig. 2. Model residual analysis involving hydrological modeling. $\mathrm{P}$ is precipitation, PE: evapotranspiration and XPRE is the set of model parameters for the preurbanisation period.

Fig. 3. GR4J model structure and calibrated parameters (Perrin et al., 2003), P is precipitation, PE: evapotranspiration, UH: unit hydrogramph .

Fig. 4. Method used to determine flow change from preurbanization to posturbanization. Grey dotted line is the estimated flow change between pre- and posturbanization. Black and green dotted lines are the mean flow of pre- and posturbanization respectively.

Fig. 5. Location of 24 paired catchments in the United States and one of the paired catchments as an example. REF_catch= reference catchment (green) and URB_catch= urban catchment (red).

Fig. 6. Urban percentages of 625 US catchment areas derived from the NLCD developed classes of 2006 (x-axis) and derived from the conversion matrix of Table 1 using the housing density map of 2010.

Fig. 7. Annual time series of the three flow characteristics (mean flow, Q05 and Q95) for the exemplar paired catchments. The solid line, urbanized catchment is the Brandywine Creek at Chadds Ford (01481000)and the control, the dashed line, nonurbanized catchment is the Choptank River near Greensboro (01491000).

Fig. 8. Distributions of the $\mathrm{R}^{\mathbf{2}}$ of the preurbanization linear relationships between the annual flows of the control and disturbed flow catchments for paired catchments and 
between the simulated and observed flows on the disturbed catchment for the model residual approach. The boxes are delimited by the 25th and 75 th percentiles, the median is indicated with a thick line and the whiskers are delimited by the 5th and 95th percent.

Fig. 9. Example of Q05 flow change estimation for the paired catchment approach. The urbanized catchment is the Brandywine Creek at Chadds Ford (01481000) and the control nonurbanized catchment is the Choptank River near Greensboro (01491000). Preurbanization (Pre) values are represented by crosses and posturbanization (Post) by dots. The dashed line and solid line are the linear regression relationships derived for the two periods

Fig. 10. Relative changes for the 24 urbanized catchments in mean flow, Q95 and Q05 (from left to right) versus urban change from the preurbanization period to the posturbanization period. White dots: nonsignificant $(\mathrm{p}>0.1)$ and black dots: significant change $(\mathrm{p}<0.1)$.

Fig. 11. Example of Q05 flow change estimation for the model residual approach. The urbanized catchment is the Brandywine Creek at Chadds Ford (01481000). The Y-and $\mathrm{X}$-axis corresponds to the observed annual flow values and the simulated flow values, respectively derived from the model calibrated on the pre-urbanization period. Preurbanization (Pre) values are represented by crosses and posturbanization (Post) by dots. The dashed line and solid line are the linear regression relationships derived for the two periods.

Fig. 12. Comparison of flow change on urbanized catchments as estimated by the paired catchment and model residual approaches. The bars exhibit the uncertainties of the model residual approach as estimated by the parameter uncertainty analysis. White dots: 
nonsignificant $(\mathrm{p}>0.1)$ for both approaches, grey dost: significant for a single approach and black dots: significant change $(\mathrm{p}<0.1)$ for both approaches. 
Pre-urbanization period

Disturbed catchment Control catchment
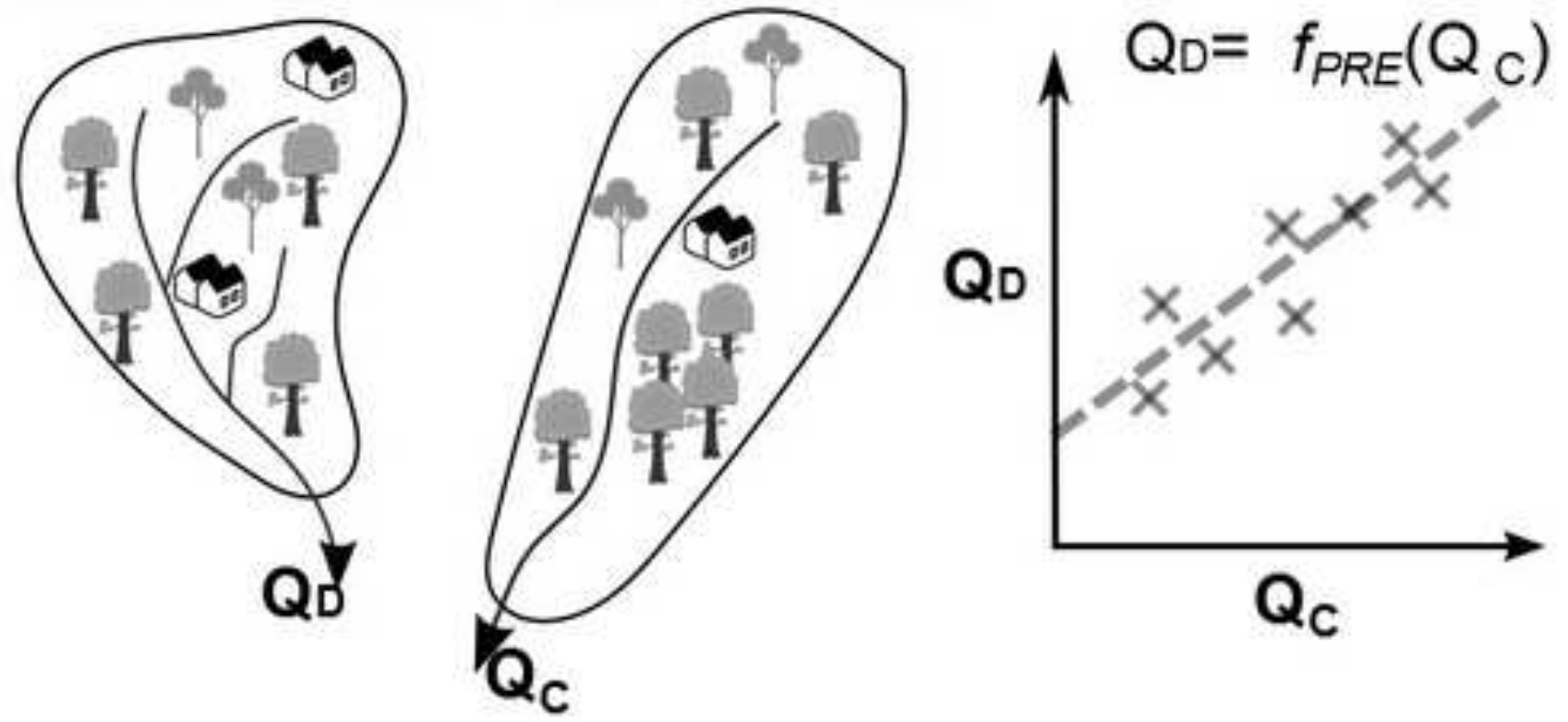

Post-urbanization period

Disturbed catchment Control catchment
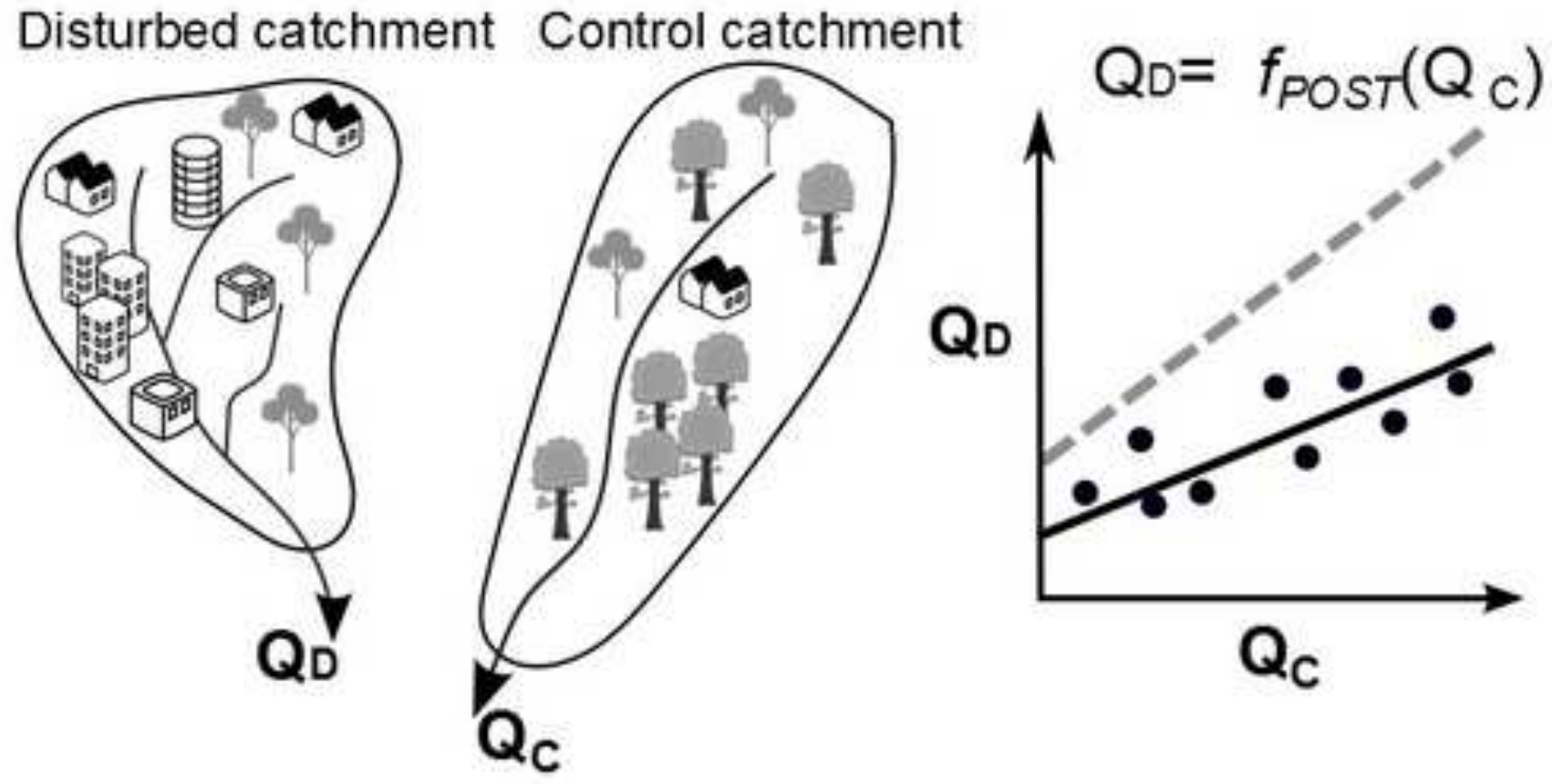

$\mathrm{QD}=$ Disturbed catchment discharge $\mathrm{QC}=$ Control catchment discharge $\mathrm{f}=$ Linear function 
Disturbed catchment Model
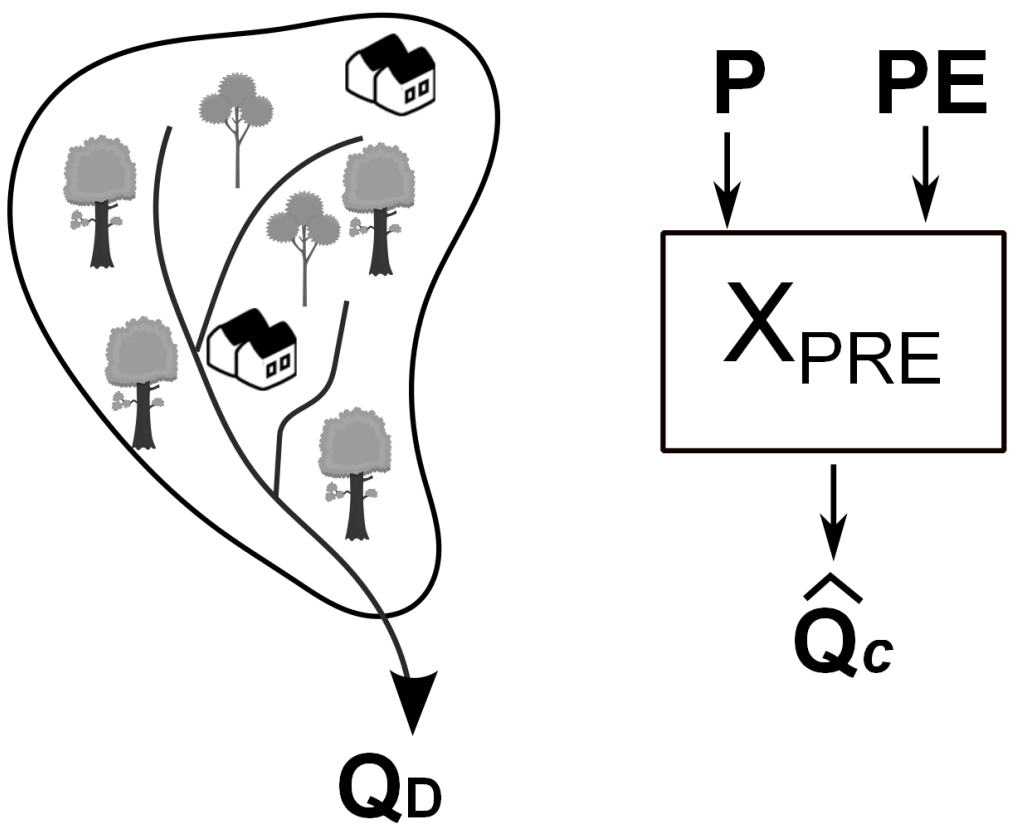

Posturbanization period

Disturbed catchment Model
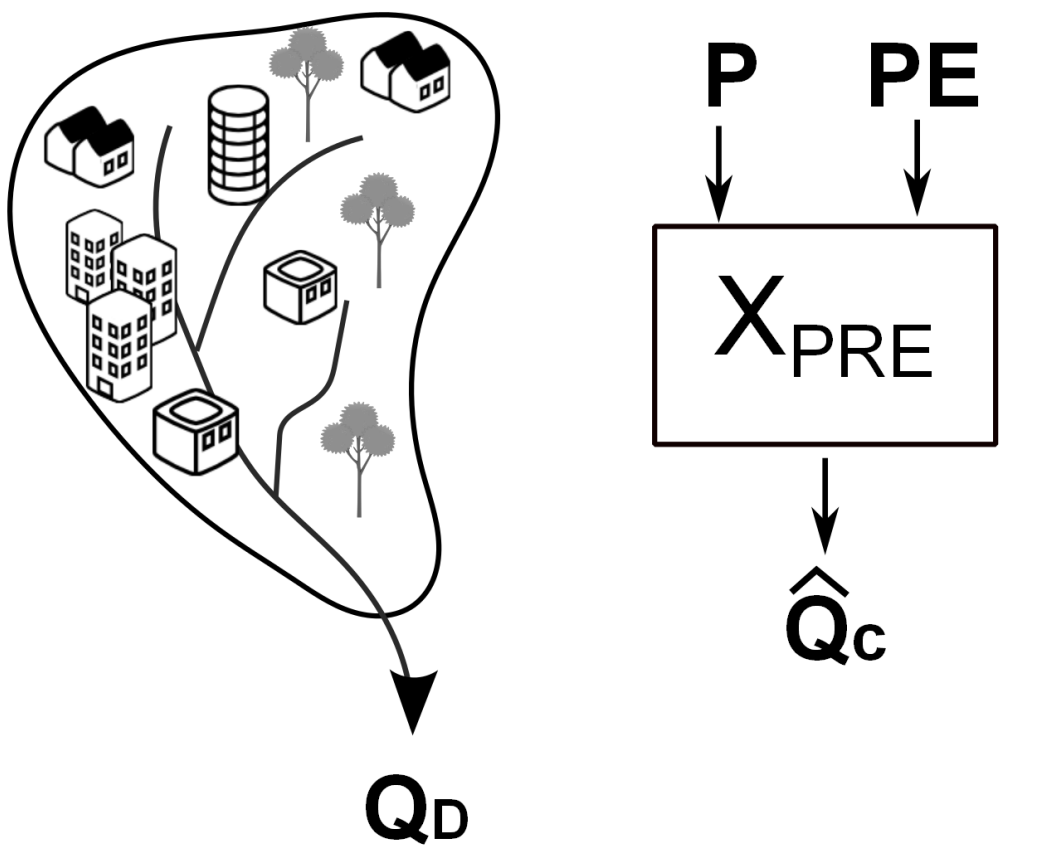
$\mathbf{f}=$ Linear function
$\mathrm{QD}=$ Disturbed catchment discharge $\mathrm{QC}=$ Control catchment discharge
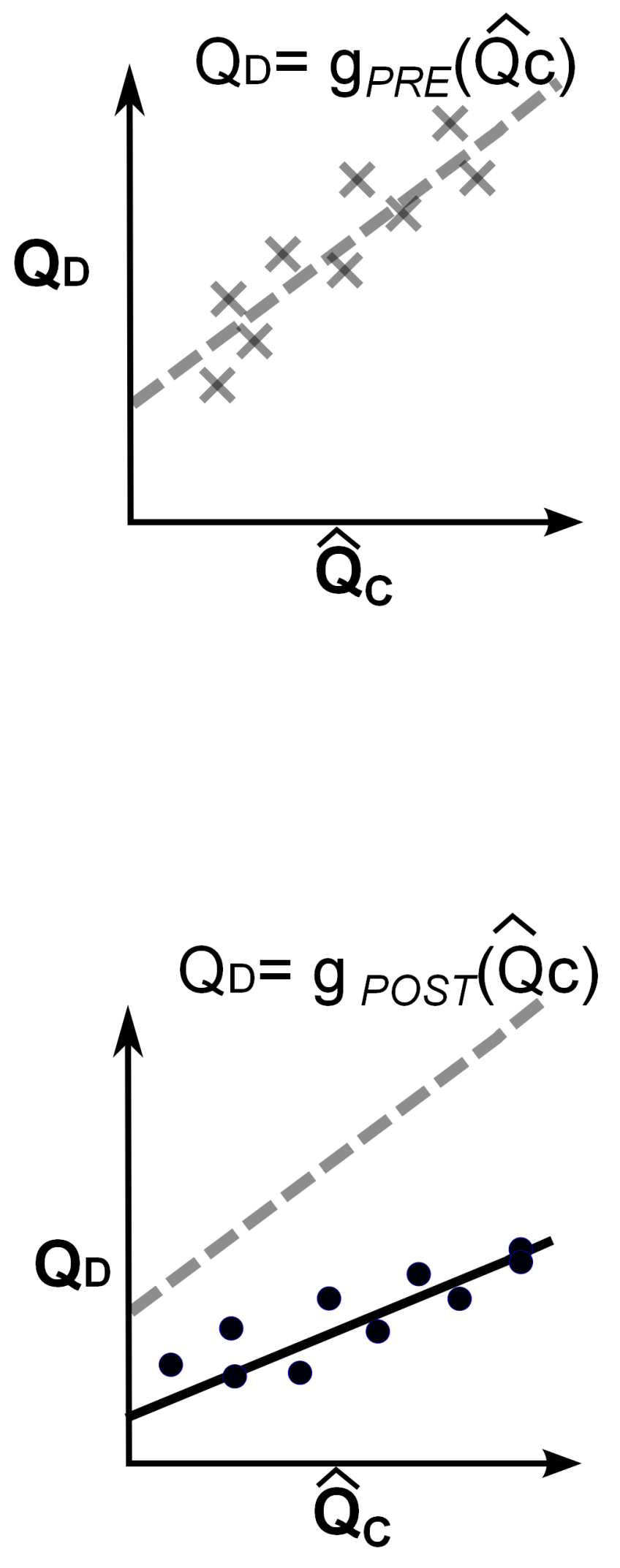


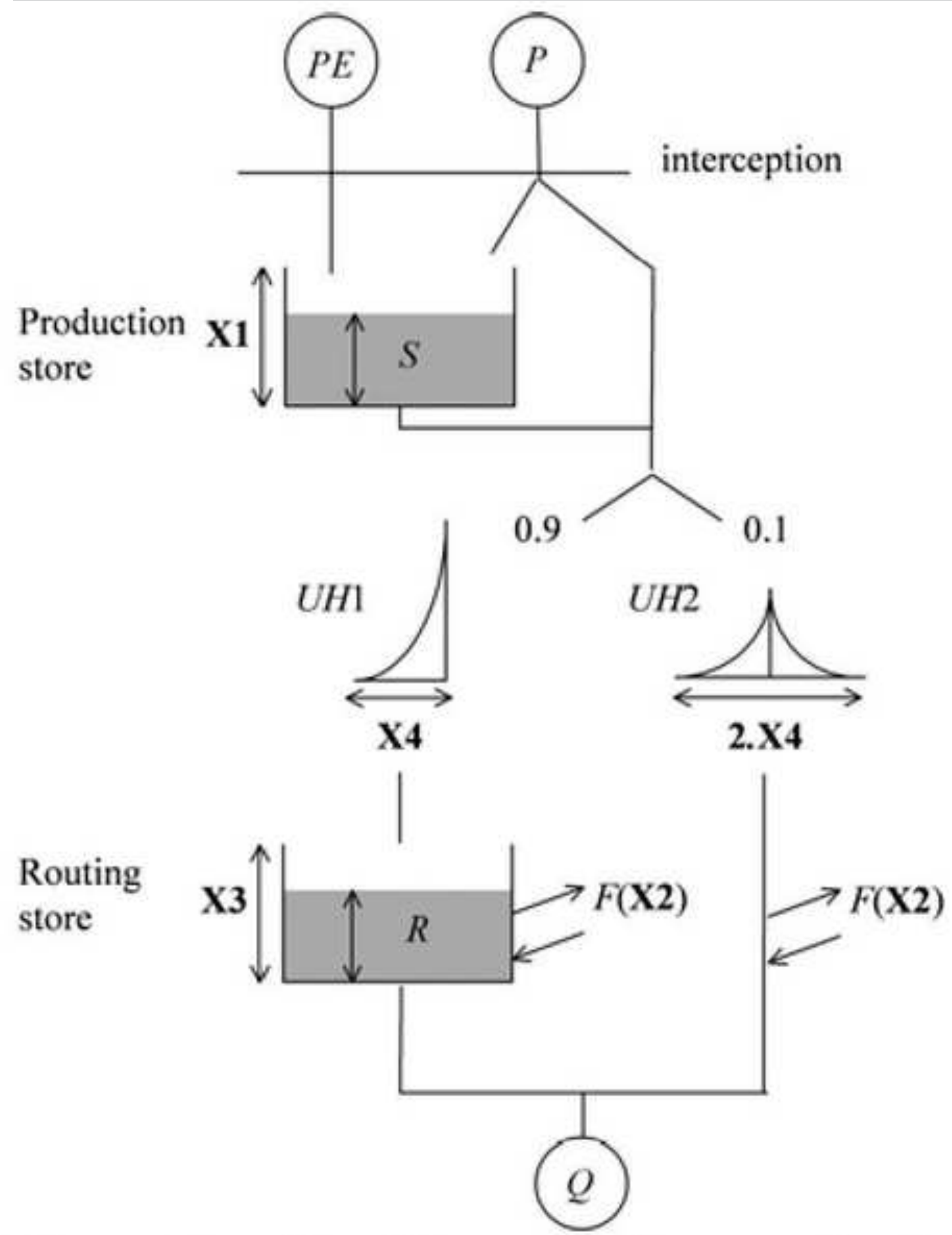

$\mathrm{X} 1$ Capacity of the production store ( $\mathrm{mm}$ )

$\mathrm{X} 2$ Water exchange coefficient $(\mathrm{mm})$

X3 Capacity of the nonlinear routing store $(\mathrm{mm})$

X4 Unit hydrograph time base (day) 


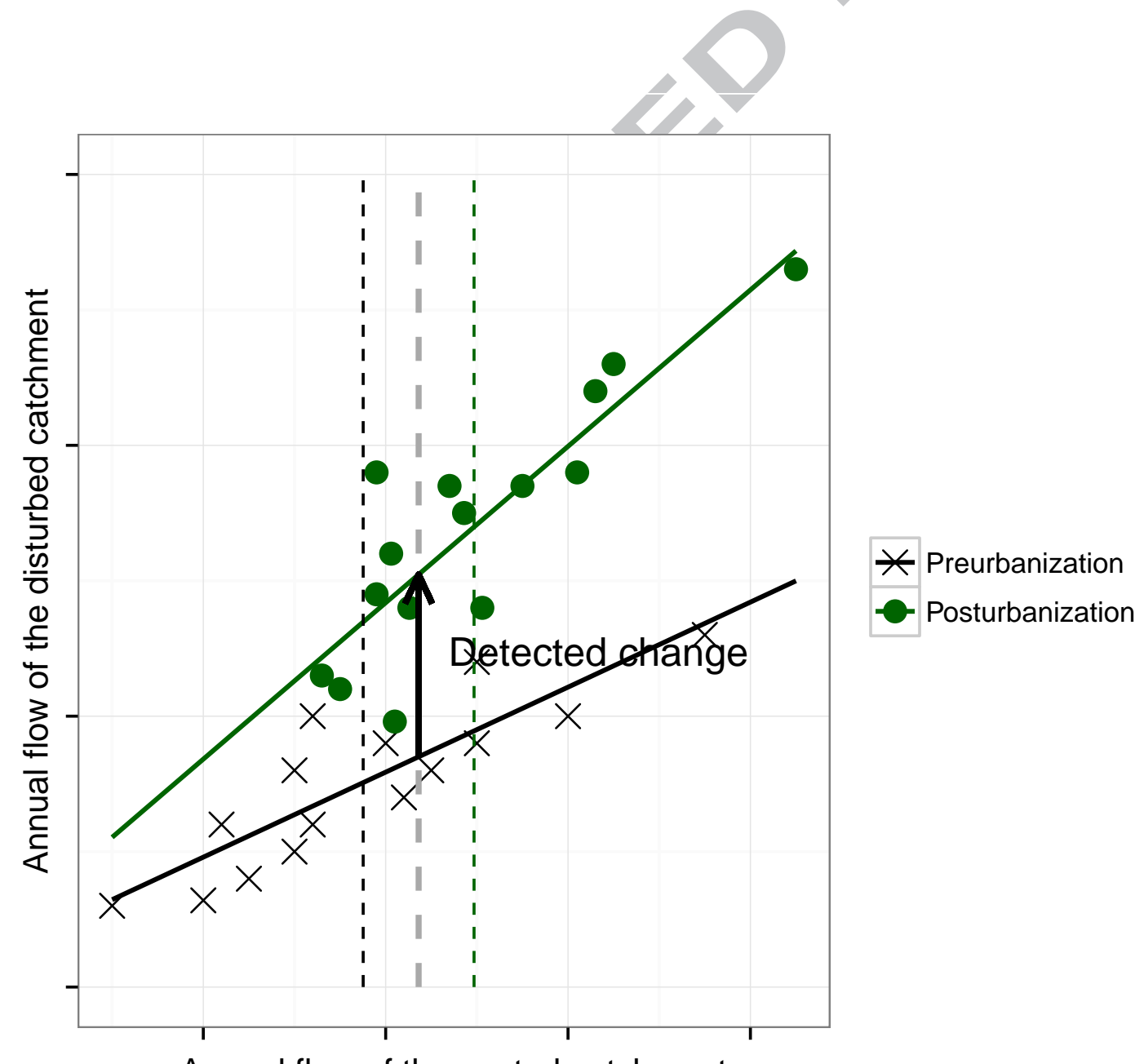

Annual flow of the control catchment 


\section{ACCEPTED MANUSCRIPT}

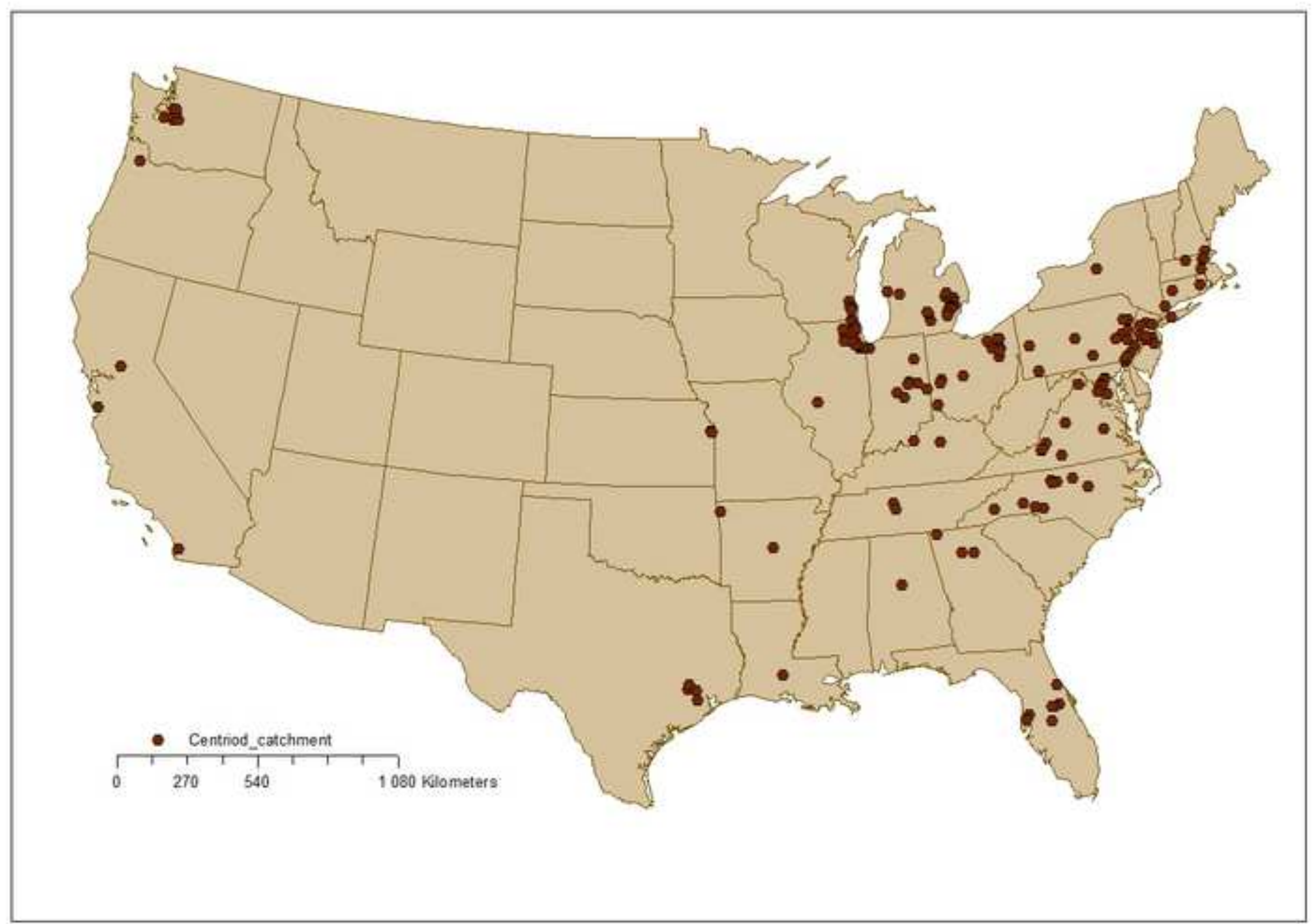




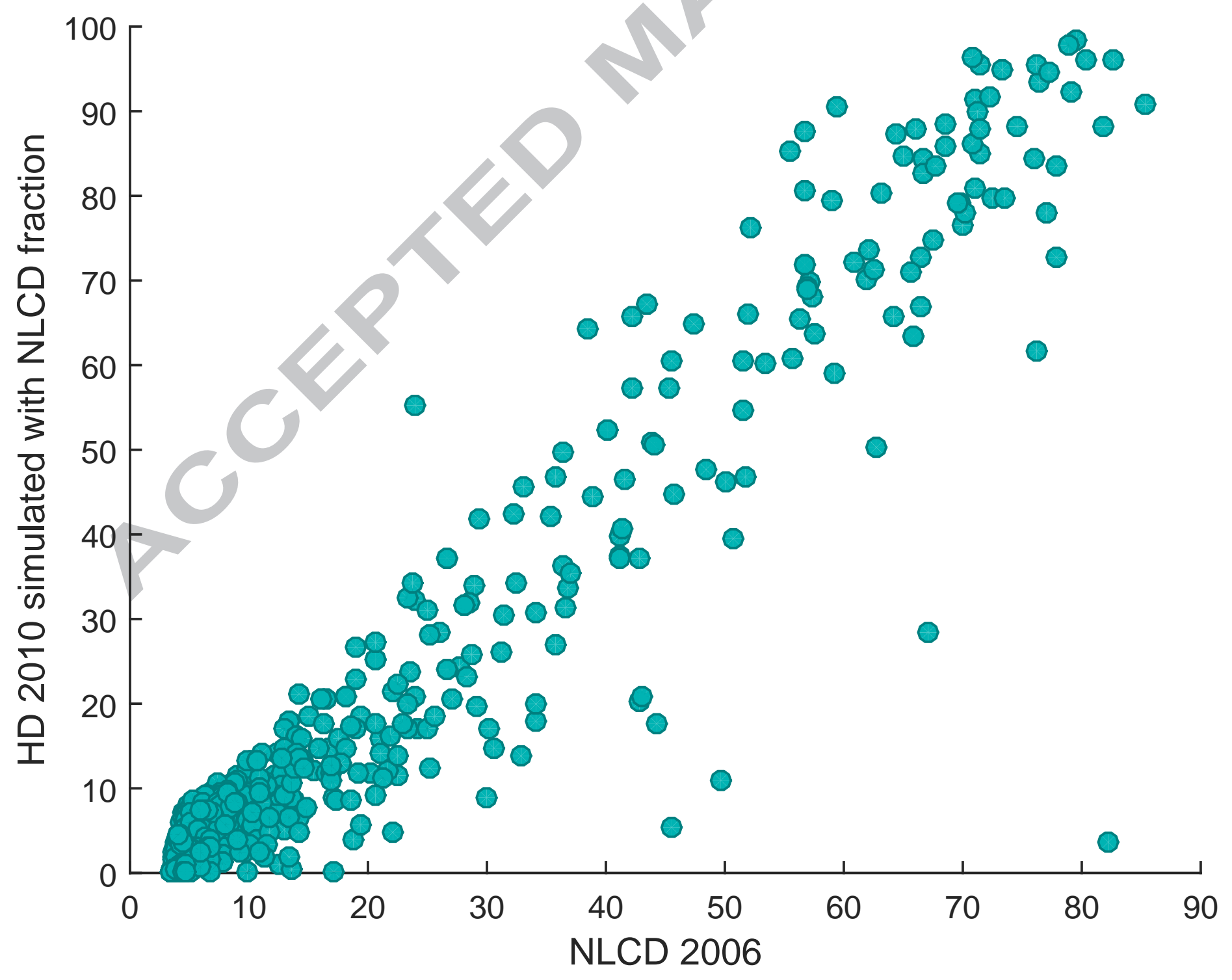



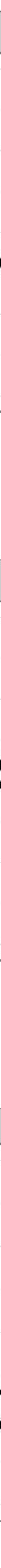

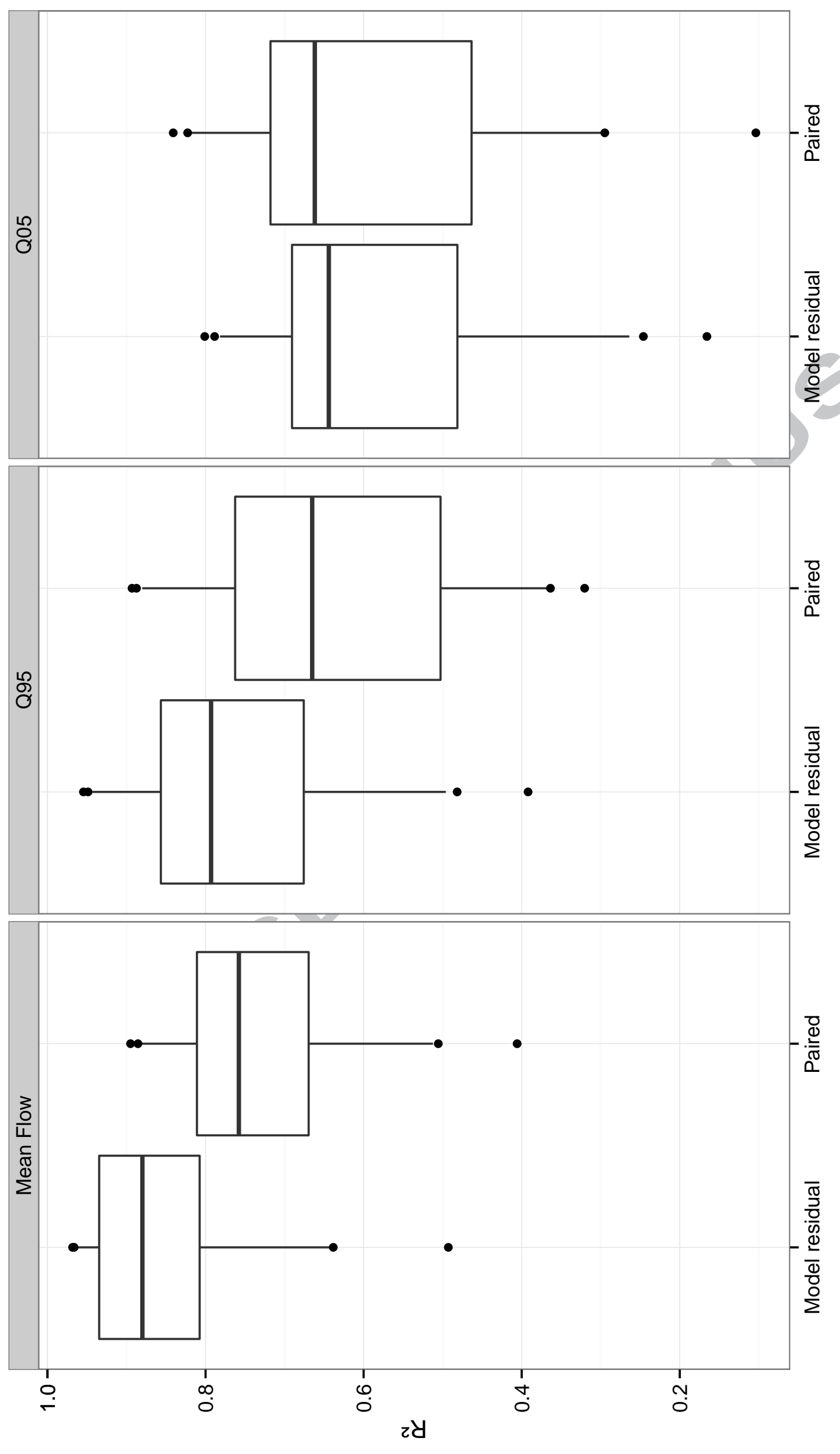


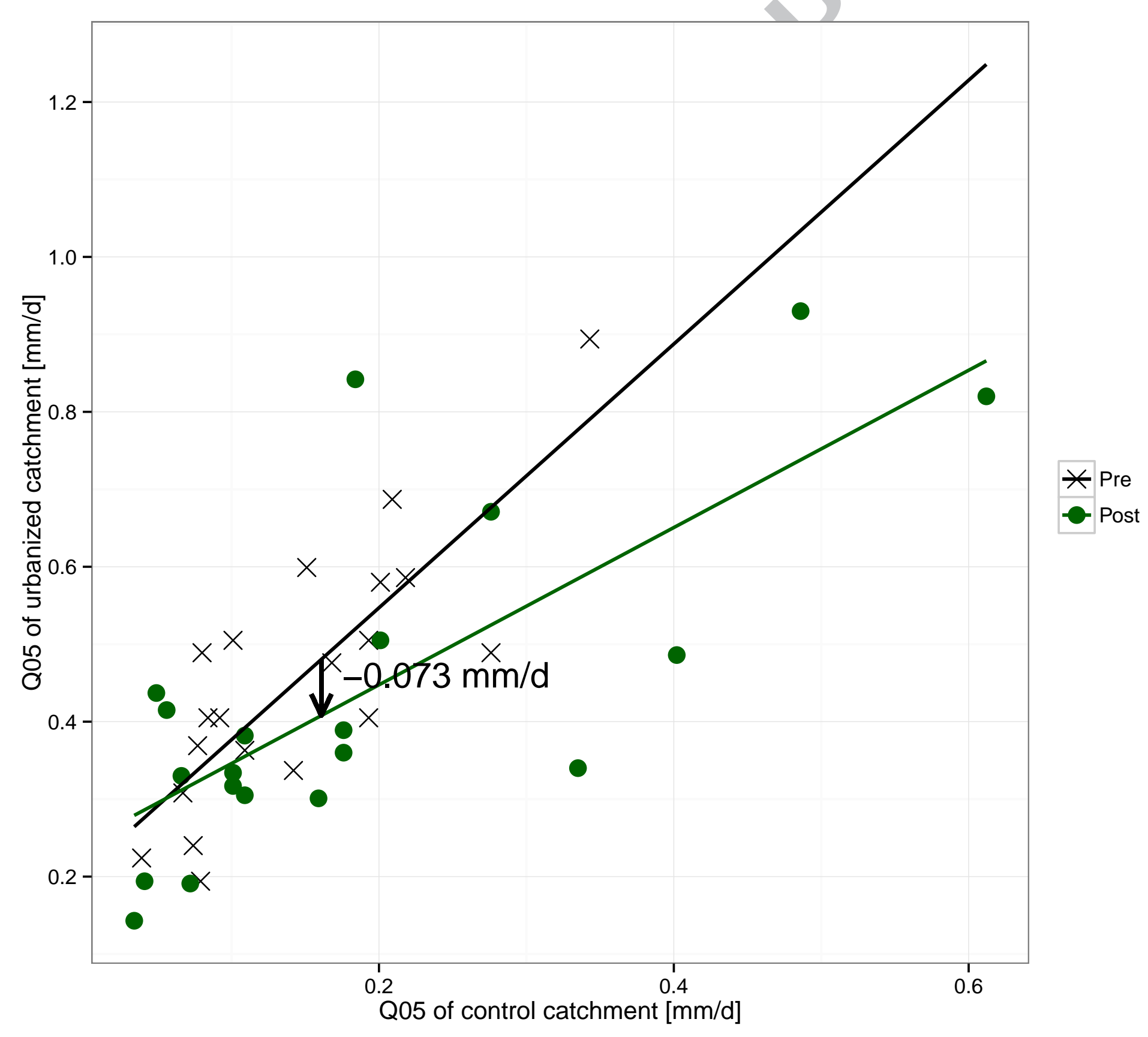




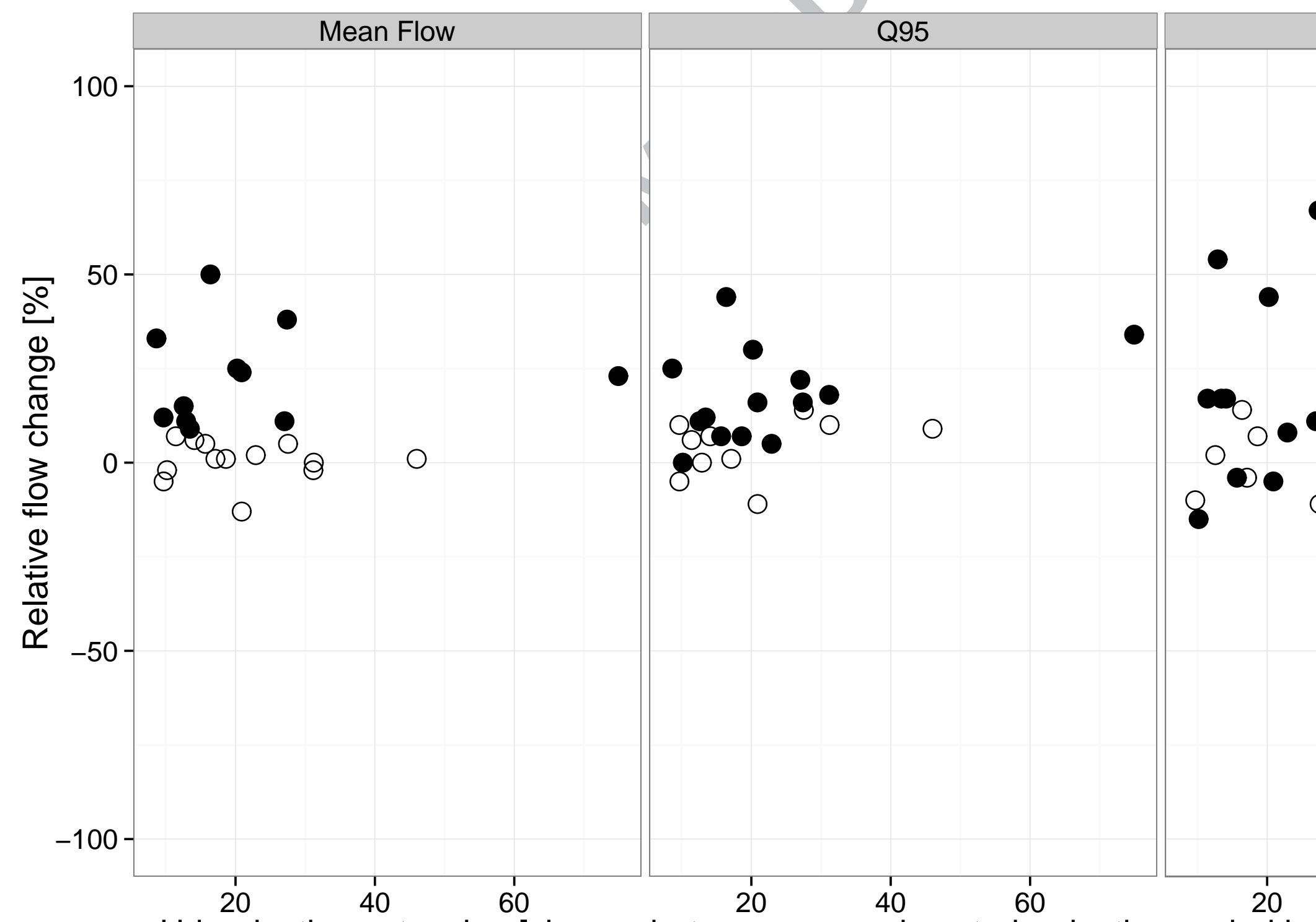

Urbanization extension [change between pre and posturbanization period in 


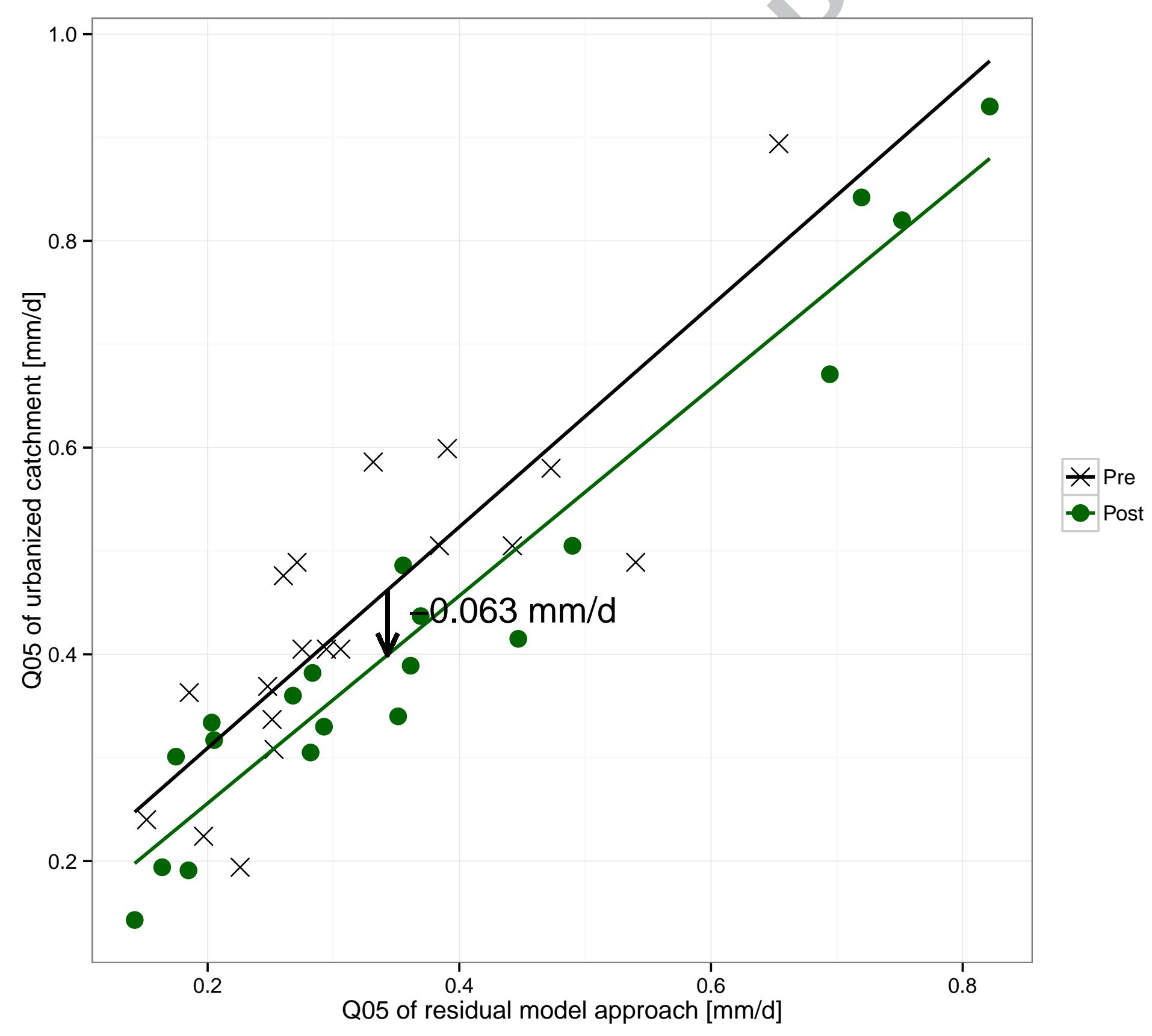



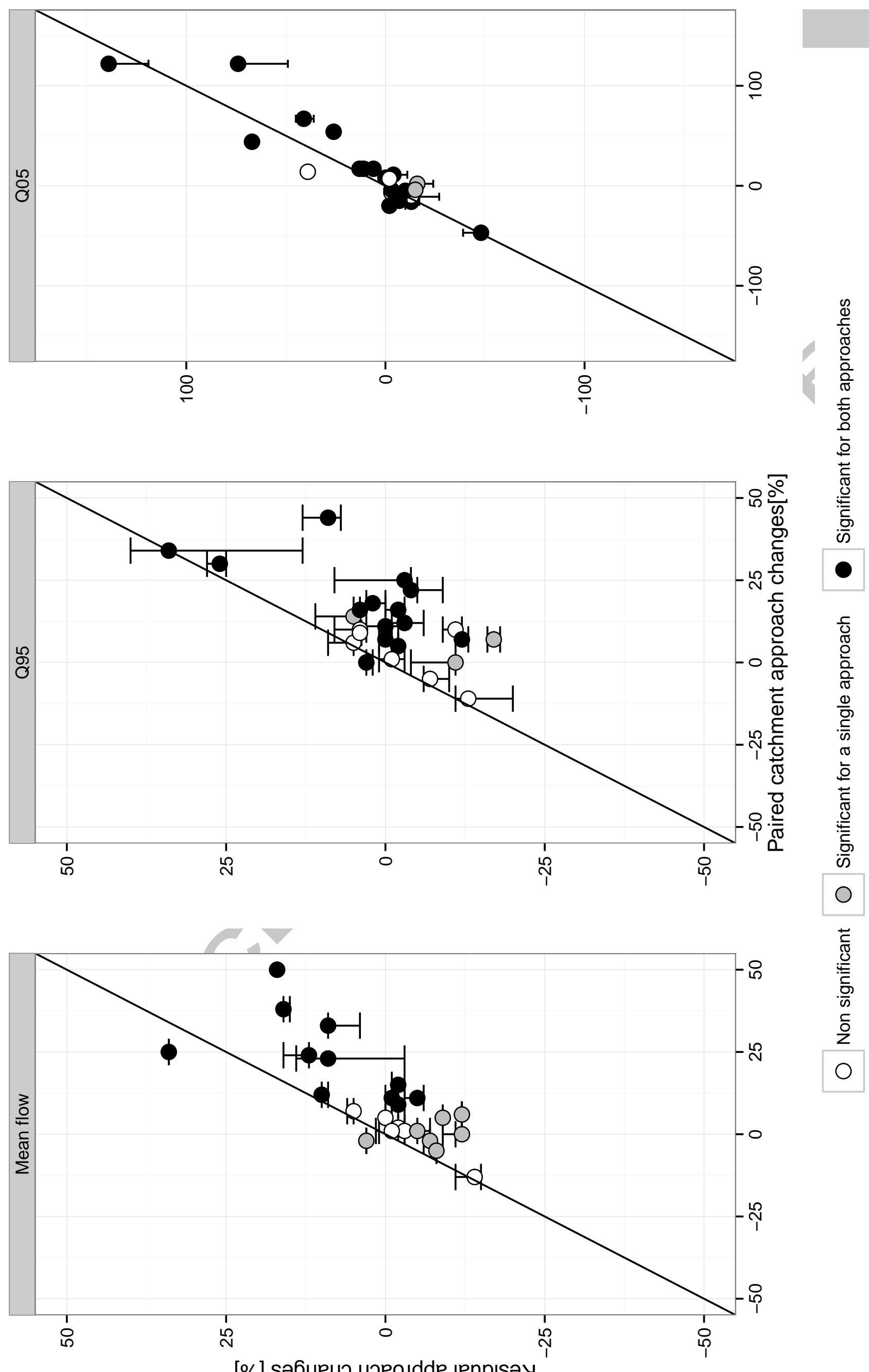

[\%] sәбиечо чәеoıdde ןenp!səy 


\section{Highlights:}

- Paired catchments is used to investigate the effect of urbanization

- Hydrological simulation is used to replace non-urban neighbor catchments

- Significantly trends on urban hydrology catchments are analyzed from 1940 to 2010 